Portland State University

PDXScholar

1980

Geology of the Columbia River Basalt in Silver Falls

State Park, Oregon

Elizabeth Storm Norman

Portland State University

Follow this and additional works at: https://pdxscholar.library.pdx.edu/honorstheses

Let us know how access to this document benefits you.

Recommended Citation

Norman, Elizabeth Storm, "Geology of the Columbia River Basalt in Silver Falls State Park, Oregon" (1980).

University Honors Theses. Paper 395.

https://doi.org/10.15760/honors.390

This Thesis is brought to you for free and open access. It has been accepted for inclusion in University Honors Theses by an authorized administrator of PDXScholar. Please contact us if we can make this document more accessible: pdxscholar@pdx.edu. 


\section{GEOLOGY OF THE COLUMBIA}

RIVER BASALT IN SILVER FALLS STATE PARK, OREGON

by

ELIZABETH STORM NORMAN

A thesis submitted in partial fulfillment of the requirements for the degree of

BACHELOR OF SCIENCE

IN

EARTH SCIENCE

Portland State University

1980 
AN ABSTRACT OF THE THESIS OF Elizabeth Storm Norman for the University Scholars Program Bachelor of Science degree in Earth Science presented January 25, 1980.

Title: Geology of the Columbia River Basalt in Silver Falls State Park, Oregon

APPROVED BY:

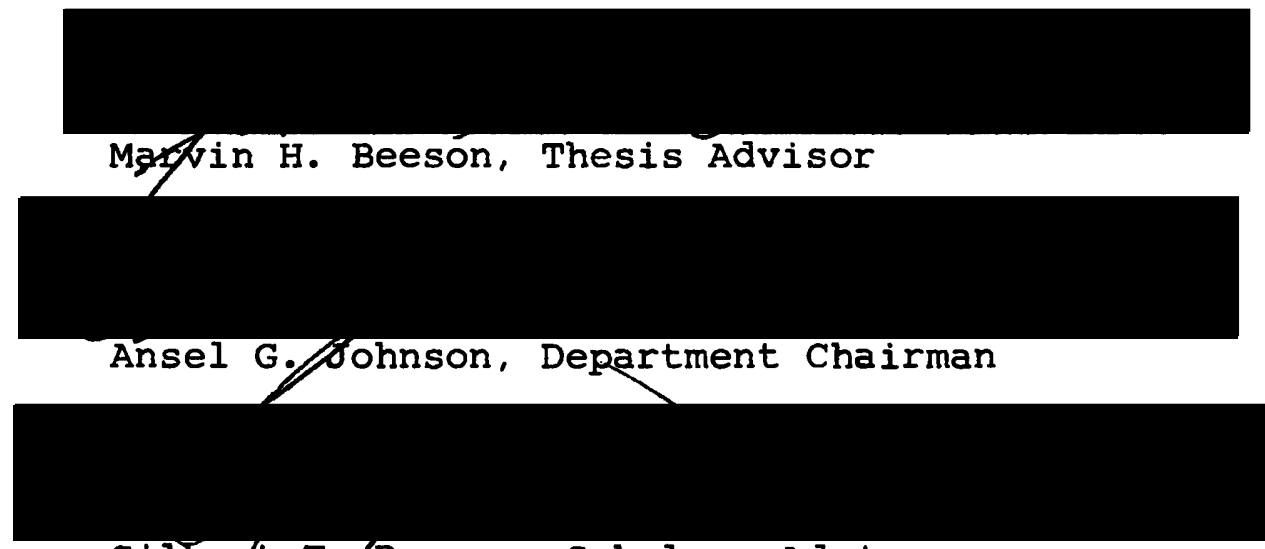

Gilbert T. Benson, Scholars Advisor

Silver Falls State Park is near the southern extent of the Columbia River Basalt Group as mapped in western oregon. The flows in the park were identified as belonging to subdivisions of the Columbia River Basalt Group on the basis of physical characteristics and trace element geochemistry. The sequence of flows present is as follows: $3-4$ flows of the Low-Mg chemical type of the Grande Ronde Basalt, 2 flows of the High-Mg chemical type of the Grande Ronde Basalt, 3 flows of the Frenchman Springs Member of the Wanapum Basalt, and one flow of anomolous geochemistry. The flows dip west to 
southwest two to three degrees on the limb of an open anticline. Two related trends are represented in the jointing pattern of the flows, $\mathrm{N} 20 \mathrm{~W}$ and $\mathrm{N} 70 \mathrm{E}$. A paleostream appearing to follow one of these trends eroded $90 \mathrm{~m}$ into the Low-Mg and High-Mg flows before its valley was obscured by the incursion of a Frenchman Springs flow. The possibility arises that this stream drainage may provide access to the coast via the coast range for the Frenchman Springs basalts. 


\section{ACKNOWLEDGMENTS}

Gratitude is expressed to the faculty of the Earth Sciences Department at Portland State University who have waited patiently for the presentation of this thesis, especially Dr. Marvin Beeson, my thesis advisor for his encouragement, suggestions and criticism. I am also indebted to my father, George Storm, for providing transportation and doing some of the leg work in the field. Finally, I express gratitude to my husband, Dave Norman, who helped in the field and at home, letting me borrow his strength as well as supplying me with support and motivation. 
TABLE OF CONTENTS

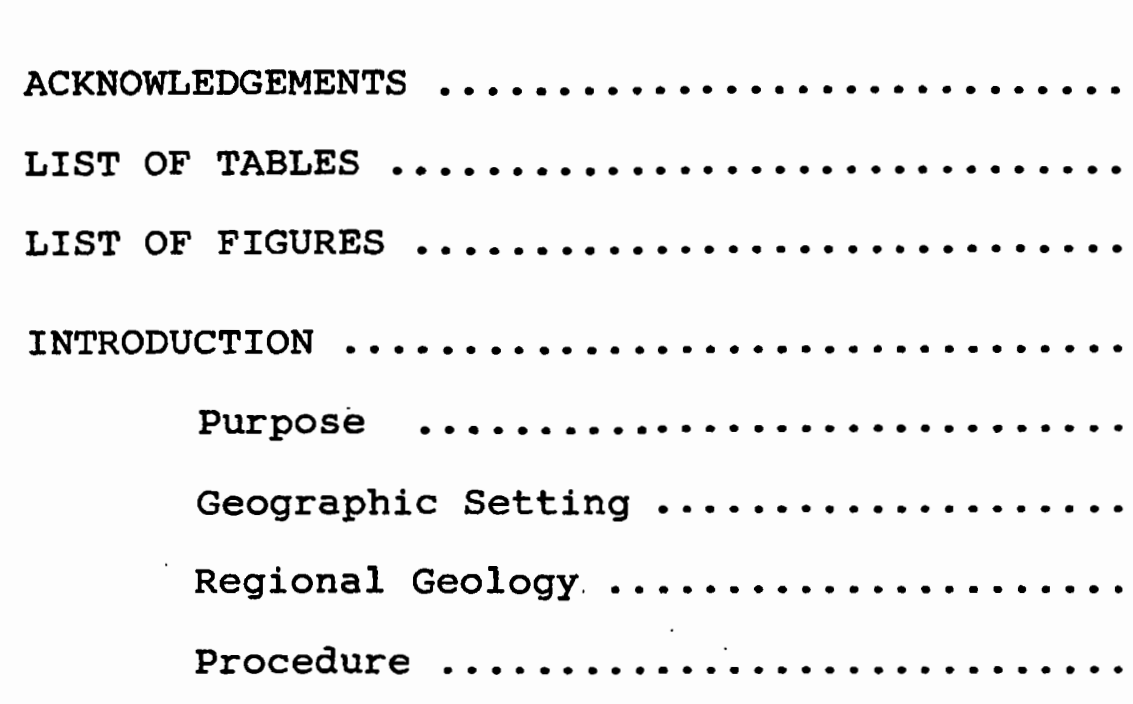

STRATIGRAPHY $\ldots \ldots \ldots \ldots \ldots \ldots \ldots \ldots \ldots$

PAGE

iv

$\mathrm{v}$

Geochemistry $\ldots \ldots \ldots \ldots \ldots \ldots \ldots \ldots \ldots$

Physical Characteristics ...........

Grande Ronde Basalt ...........

Vantage horizon ..............

Frenchman Springs Member of Wanapum Basalt

Correlation $\ldots \ldots \ldots \ldots \ldots \ldots \ldots \ldots$ 


\section{IIST OF TABLES}

TABLE

PAGE

I Sodium, Iron, and Trace Element Geochemical Analyses $\ldots \ldots \ldots \ldots \ldots \ldots \ldots \ldots \ldots \ldots$

II Frenchman Springs Member - Geochemical Comparison of Flows at Silver Falls State Park with Flows from the Type Localities and the Clackamas River Area

II Grande Ronde Basalt: High-Mg and Low-Mg

Geochemical Types - Geochemical

Comparison of Flows at Silver Falls

State Park with those from other

Areas .......................... 14 


\section{LIST OF. FIGURES}

FIGURE

PAGE

1 Location of Cascade Range and thesis area in

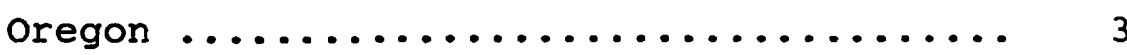

2 Distribution of the Columbia River Basalt

Group in Oregon, washington, and Idaho ... 3

3 Anticlinal folding in the Silver Creek area .. 5

4 Generalized stratigraphic column for the

Columbia River Basalt Group in Silver

Falls state Park ..................... 10

5 Distribution of samples into chemical groups

on the basis of $\frac{\mathrm{Na}}{\mathrm{Sm}}$ vs. $\frac{\mathrm{Sc}}{\mathrm{Th}} \ldots \ldots \ldots 11$

6 Distribution of samples into chemical groups

on the basis of $\frac{\mathrm{Na}}{\mathrm{La}}$ vs. $\frac{\mathrm{Sc}}{\mathrm{Th}} \ldots \ldots \ldots . \ldots 12$

7 Stream profile along silver creek and its

North Fork showing selected stratigraphic

sections and the position of the

geochemical samples ................ 16

8a North Falls showing blocky jointing in the

Frenchman Springs flows. Lower Fence is

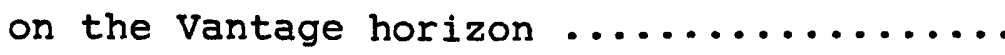

b Middle North Falls at the High-Mg/Low-Mg

Grande Ronde Basalt boundary showing thick 
entablature and basal columns of the High-Mg $\ldots \ldots \ldots \ldots \ldots \ldots \ldots \ldots \ldots$

9a South Falls at the Vantage horizon .........

b Winter Falls showing channeling at the contact between the +1 and +2 flows of the Frenchman Springs Member ............

10a Horizontal columns near the edge of the intracanyon portion of the Frenchman Springs Member $\ldots \ldots \ldots \ldots \ldots \ldots \ldots \ldots \ldots$

b The intracanyon flow at Elbow Falls, joints dipping 40 southeast $\ldots \ldots \ldots \ldots \ldots \ldots \ldots$

11 Possible valley configurations which the

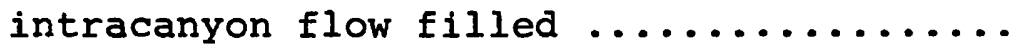

12 Geologic Map of Silver Falls State Park ...... 40

13 Geologic cross sections through Silver Falls State Park $\ldots \ldots \ldots \ldots \ldots \ldots \ldots \ldots \ldots$ 


\section{INTRODUCTION}

During recent years, the Columbia River Basalt Group has been extensively subdivided and grouped by flows into mappable units that are distinct physically, lithologically, paleomagnetically and/or chemically (Swanson and others, 1979). These flow groups have been useful in unraveling the geologic history, in determining the structure and in establishing the stratigraphy of areas where Columbia River basalt dominates the outcrop exposures.

\section{Purpose}

Field study was conducted in the Silver Falls state Park area for the following reasons: 1) it provides knowledge of the Columbia River basalt near the basalt's southern extreme in western oregon, 2) flow units in this area had not previously been identified geochemically, 3) good exposures in cliffs and waterfalls are easily accessible by roads and trails, 4) the limited extent of the area makes it appropriate to a Bachelor's thesis. The primary aim of the exercise has been the development of a stratigraphic section for the flows in the area with an accompanying geologic map. Heavy emphasis has been placed on field mapping of flows and analysis of flow samples by trace element geochemistry.

\section{Geographic setting}

Silver Falls State Park, Marion County, Oregon, is located in the center of the Lyons Quadrangle in T. $8 \mathrm{~S}$. , 
R. 1 E. in the foothills of the Western Cascades (Figure 1). Access is by way of oregon State Highway 214 east from Salem. The top of the resistant Columbia River basalt forms a heavily farmed, gently rolling surface that is deeply dissected by streams such as Silver Creek which contain numerous waterfalls where the streams cut into the basalt flows. The canyon of Silver Creek is heavily forested with evergreens forming a canopy over an abundant undergrowth.

\section{Regional Geology}

During the Miocene, the Columbia Plateau was formed in Oregon, Washington, and Idaho of flood basalts extruded episodically from an extensive fissure system in the eatern portion of the region. The tholeiitic basalts reach an accumulated thickness of up to $1500 \mathrm{~m}$ maximum east of the Cascades. The extent of the flows west of the Cascades indicates that a structural or topographic low existed during the Miocene between the Columbia and Clackamas Rivers (Figure 2).

In the area east of Salem, flows of the Columbia River Basalt Group covered an erosional topography that had developed on the oligocene marine sedimentary rocks of the Illahe Formation (Thayer, 1939). The Illahe Formation was mapped by Peck and others (1961) as part of The Little Butte Volcanic Series but as a suggested correlative of the Scapoose Formation, which also contains marine sedimentary rocks. In the valley of Silver Creek, Barlow (1955) 


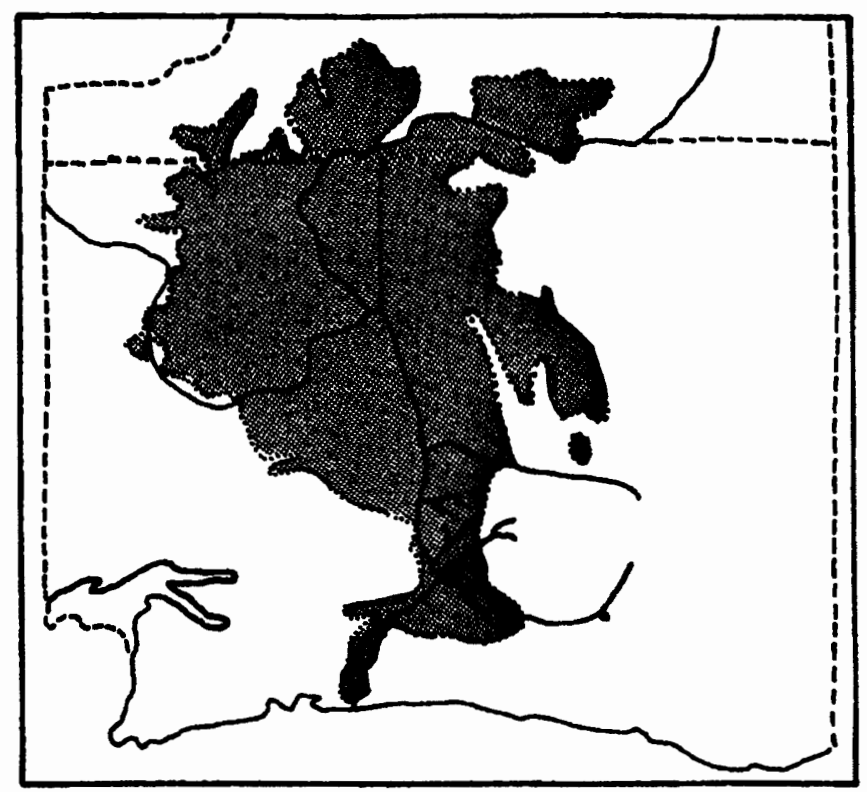

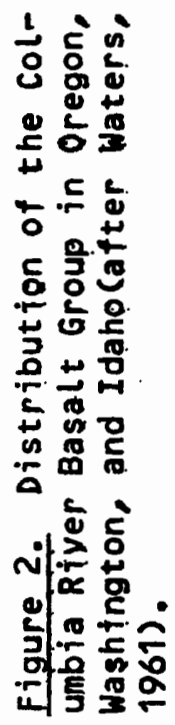

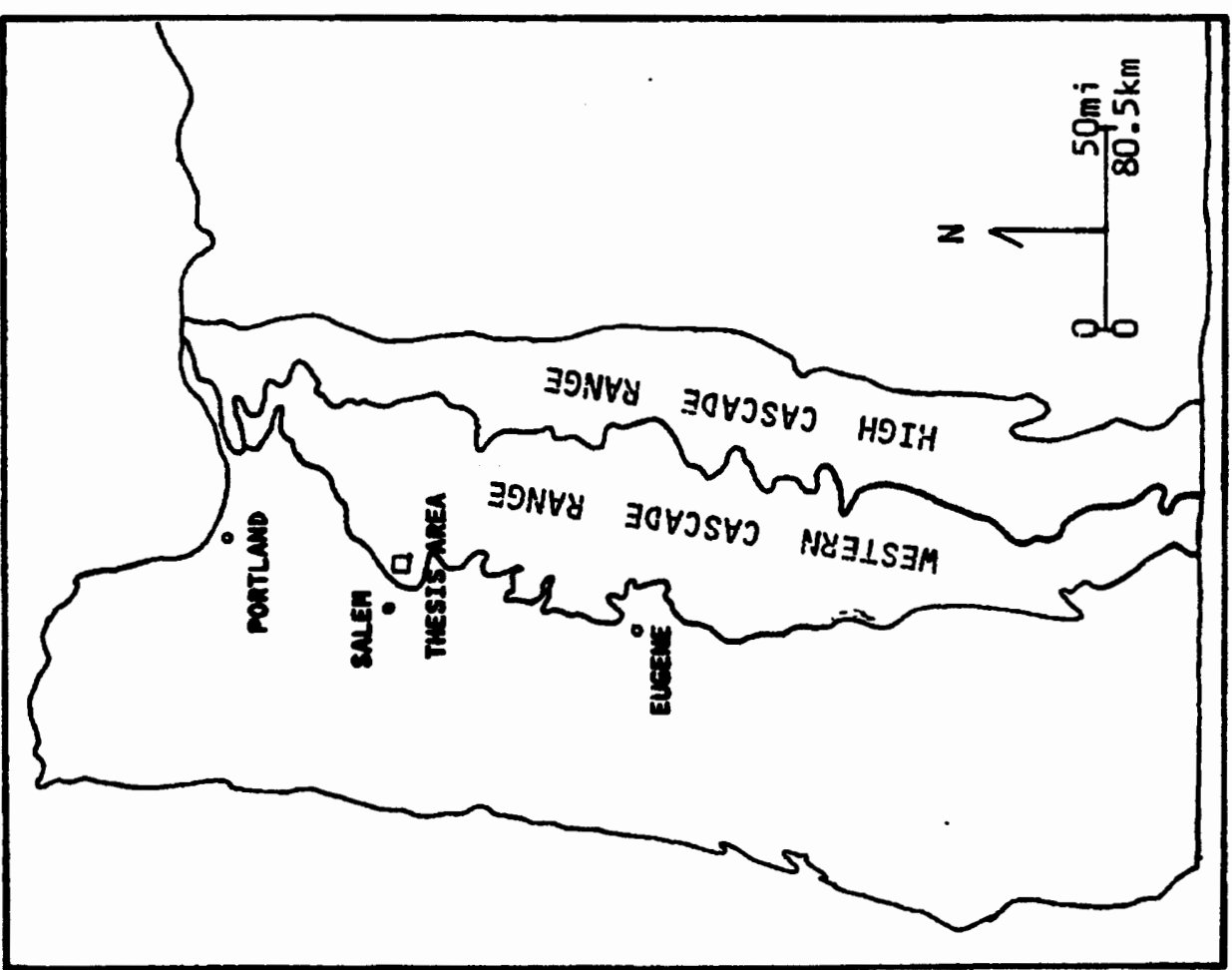

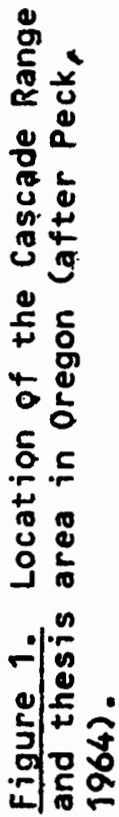


observed a minimum thickness of Columbia River basalt flows of $125 \mathrm{~m}$ and the presence of six individual flows. Time between certain flows was sufficient to allow the development of soils and even forests, as well as deep canyons. Deep weathering of the top flow formed a lateritic soil which was partially eroded before the deposition of the tuffs and breccias of the Fern Ridge Formation which have been grouped with the Sardine Formation (Peck and others, 1964). The incision of Silver Creek through the Fern Ridge Formation into the Columbia River basalts exposed the basalt flows. Both Thayer (1939) and Barlow (1955) mapped the flows as stayton Lavas tentatively correlated to the Columbia River basalt, but Peck and others (1964) included this area in their reconnaissance geologic map of the Western Casade Range and mapped the Stayton Lavas as Columbia River basalt.

Silver Falls State Park lies near the western edge of the Western Cascade Range (Figure 1). The High Cascades further to the east are little deformed while the older Western Cascades units are flexed in a series of en echelon, open, undulating folds. The axes of the folds are kilometers apart with the limbs generally showing less than 10 degrees of dip (Peck and others, 1964). Thayer (1939) shows the axis of the Mehama Anticline trending northeast to southwest and passing about $10 \mathrm{~km}$ south of the Park (Figure 3). The willamette syncline is about $10 \mathrm{~km}$ to the 


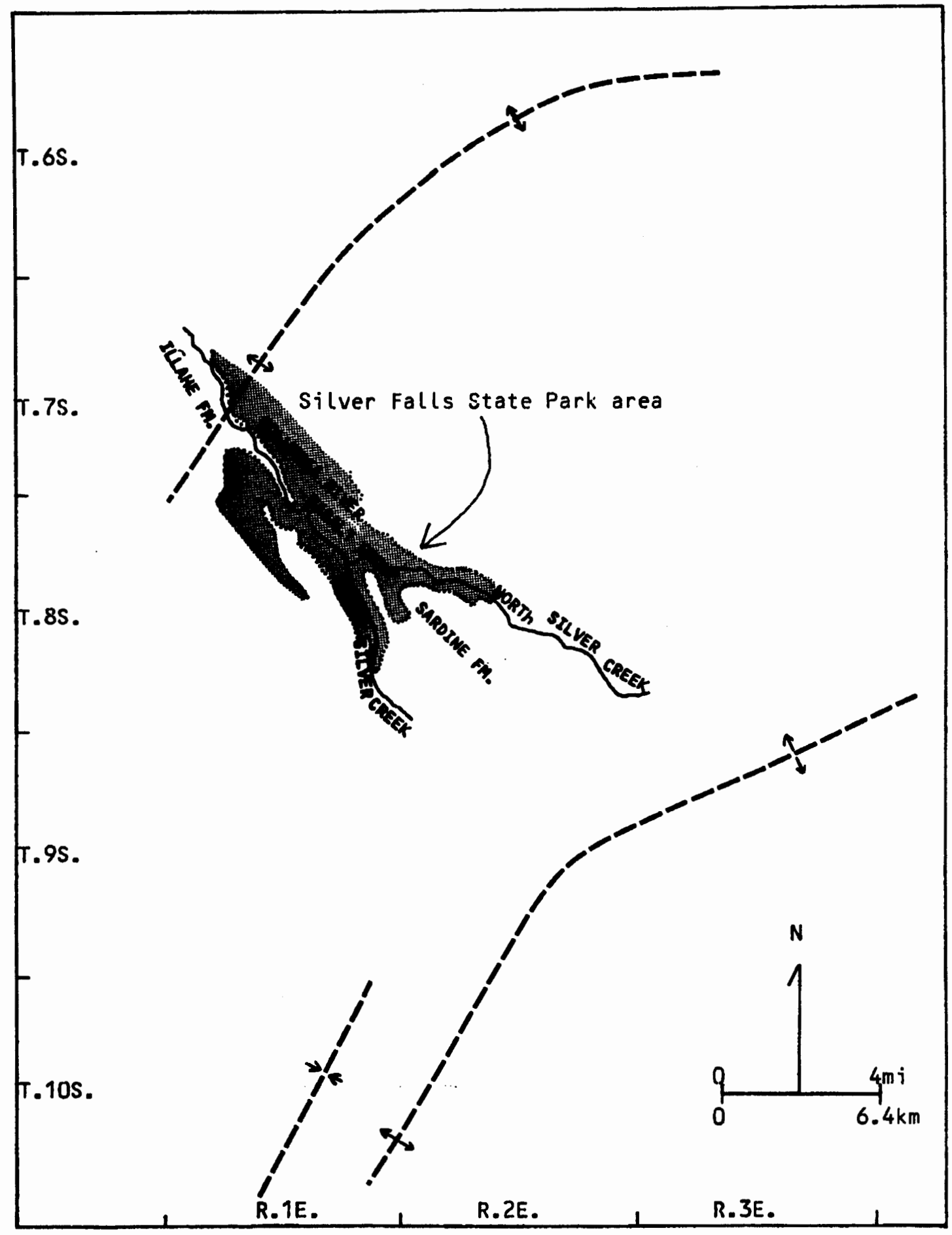

Figure 3. Anticlinal folding in the Silver creek area. (after Peck, 1964) 
east, having a north plunging axis (Thayer, 1939). Reconnaissance mapping of the Western Cascades (Peck and others, 1961), however, shows two gentle anticlines about $25 \mathrm{~km}$ apart with convex north axes swinging from $N 35^{\circ}, \mathrm{E}$ on the west to $\mathrm{N} 65^{\circ} \mathrm{E}$ on the east. The area of Silver Falls state Park lies halfway between the two axes near the centers of the curves (Figure 3 ).

\section{Procedure}

The prodecure followed began with reconnaissance field work in the spring of 1979 to tentatively establish the units being dealt with and to establish their extent. Preliminary identification of the flows as Yakima Basalt of either the Frenchman Springs Member of the Wanapum Basalt or of High-Mg or Low-Mg chemical types of the Grande Ronde Basalt was based on the phyric nature of the former, the grain size and jointing characteristics of the latter, and the presence of the intervening Vantage horizon.

Fresh samples were collected from the middle of each identified flow for geochemical analysis. Care was taken to avoid weathered samples wherever possible. Fluxgate magnetometer readings were taken near the base of flows. Flow thicknesses were measured with the aid of an altimeter to $\pm 5 \mathrm{~m}$. Geochemical analysis was then used to further identify each flow. The procedure followed for Instrumental Neutron Activation Analysis (INAA) is discussed next. 


\section{STRATIGRAPHY}

\section{Geochemistry}

Previous work by Nathan and Fruchter (1974) demonstrated that INAA could be used to compare concentrations of selected elements in order to differentiate between some units within the Columbia River Basalt Group. This method has been tested extensively and been found reliable in the Portland area (Beeson and others, 1976) and in the Clackamas River drainage (Anderson, 1978).

Samples collected as a continuous section along North Creek, along with isolated samples expected to help solve mapping difficulties (see map for locations) were brought to the lab and crushed to be irradiated in the Reed TRIGA Reactor. The experimental method and some of the theory behind it has been described by Gordon and others (1968). The samples were irradiated May 8, 1979 at 1:00 am PST for one hour. Elemental concentrations for $\mathrm{Na}, \mathrm{K}, \mathrm{Fe}, \mathrm{Co}, \mathrm{La}$, $\mathrm{Sm}, \mathrm{Lu}, \mathrm{Sb}, \mathrm{Sc}$, and $\mathrm{Yb}$ were determined from the first count on May 15, 1979. Concentrations were calculated for Fe, Co, $\mathrm{Ba}, \mathrm{Sc}, \mathrm{Cr}, \mathrm{Eu}, \mathrm{Th}, \mathrm{Nd}, \mathrm{Ce}, \mathrm{Lu}, \mathrm{Yb}, \mathrm{Hf}$ using the data from the second count on May 27, 1979. The standard for the calculations was a 32 minute count on a BCR-1 sample (Flanagan, 1973) that was irradiated and analyzed with the other samples.

Not all of the elements were found useful in distin- 
guishing between flow groups (Table I). For this work, Sm, Fe, and Eu had higher values for Frenchman Springs flows while the Low-Mg and High-Mg values overlapped. High-Mg could be separated out as low in La and Ce. Low-Mg was found to be depleted in Sc and enriched in $T h$ relative to the other two groups. Cr also served to distinguish between Low-Mg and High-Mg, with High-Mg being enriched (Figure 4, Table I).

INAA may be used to identify groups of flows, but not to distinguish individual flows. Plots of quantities of reliable elements and ratios of elements show grouping of samples that agree with previously obtained results for these groups in other areas and corroborate the assignments of flows to groups made in the field (Figures 5,6). There does seem to be a systematic difference between the data from this experiment and data from previous ones using the same equipment (Tables II,III and Figures 5,6, West Linn, Clackamas River, and Silver Falls). For example, La values for Frenchman Springs are close to 28 or 29 ppm whereas the PEG project (Beeson, Johnson, and Moran, 1976) reported values closer to $25 \mathrm{ppm}$. For High-Mg the La values are around $22 \mathrm{ppm}$, compared with $20 \mathrm{ppm}$ in the PEG report. For Frenchman Springs Fe is $13 \%$, compared with $10 \%$ found in localities cited above. As Figure 5 shows, ratio plots of values from West Linn (Beeson, Johnson, and Moran, 1976), Clackamas River (Anderson, 1978), and Silver Falls fall 


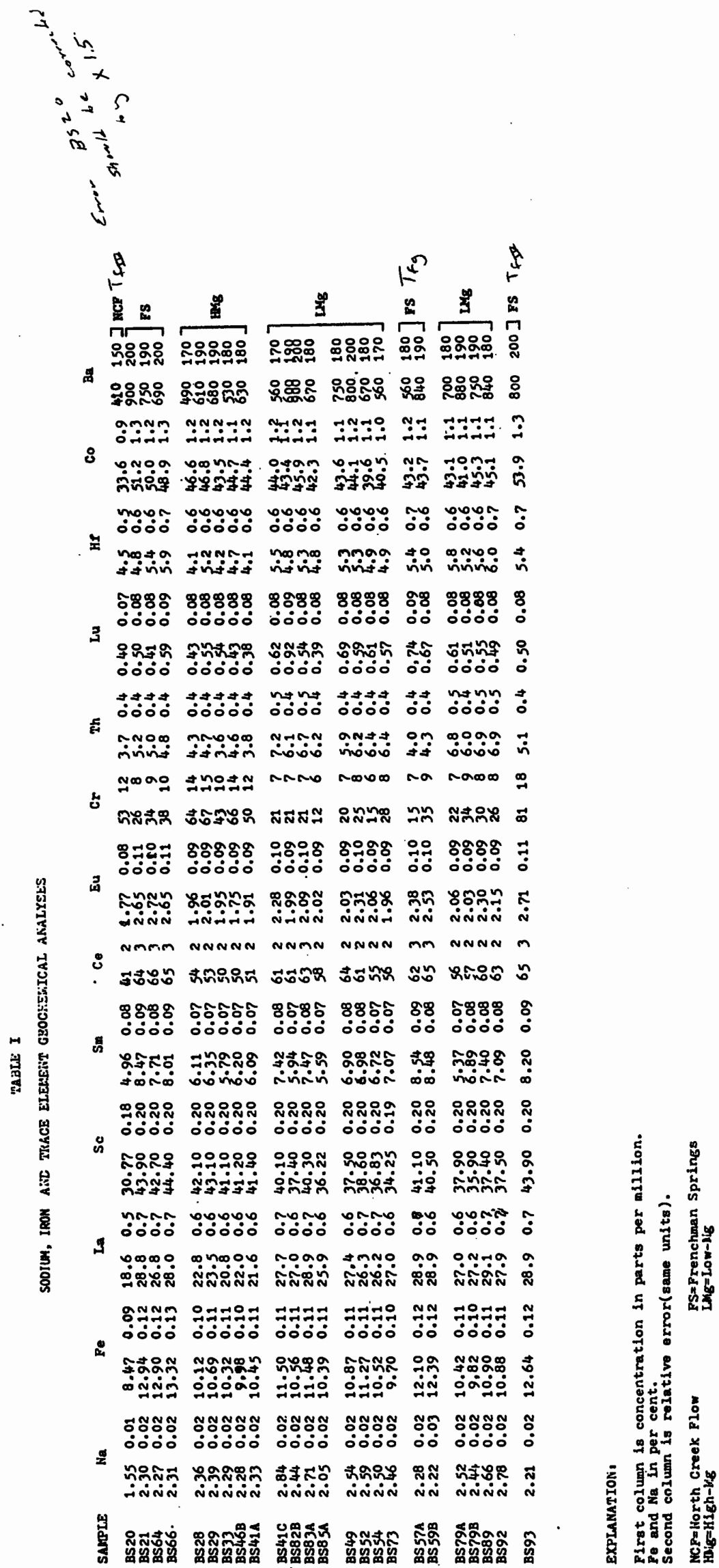




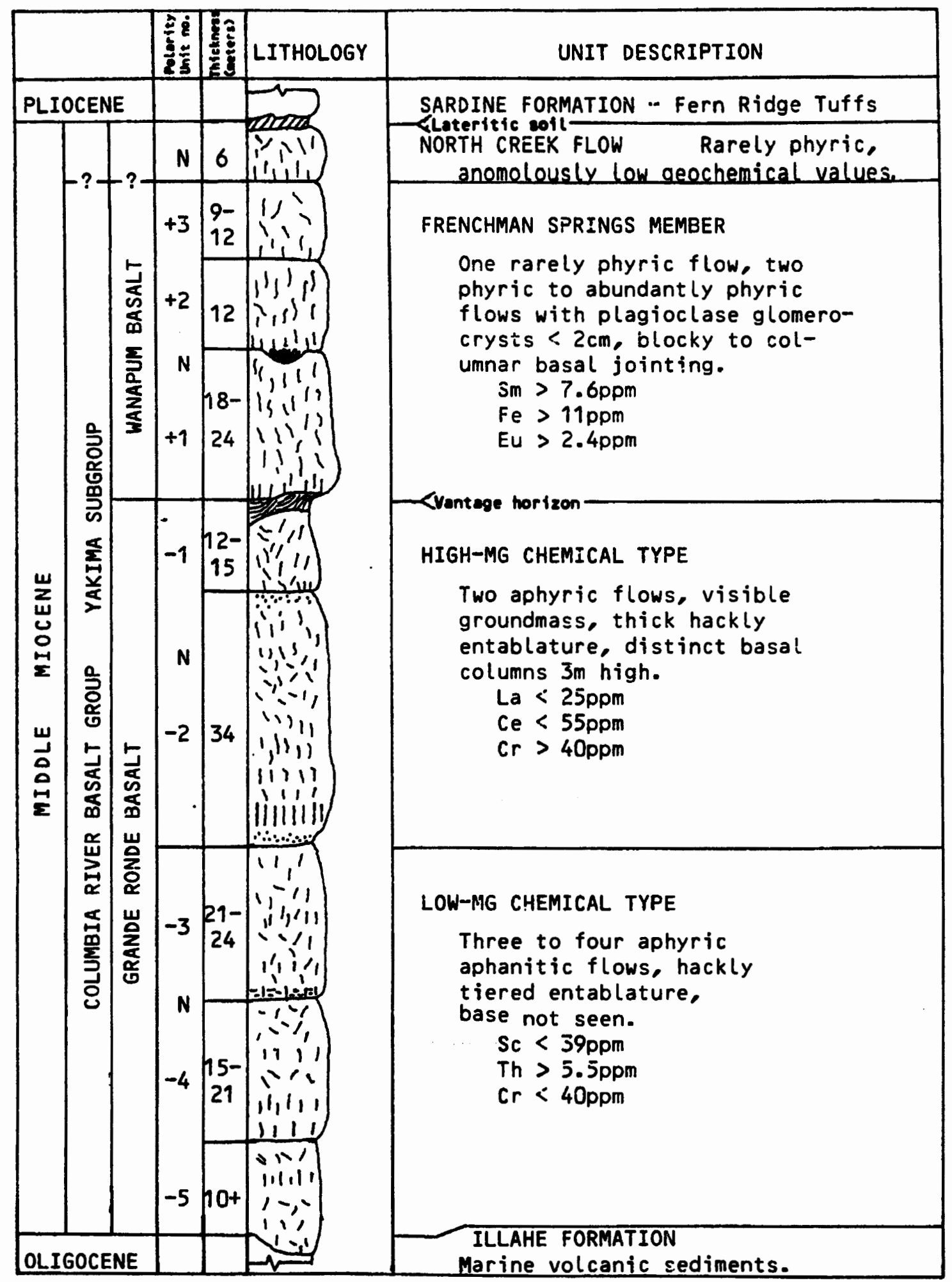

Figure 4. Generalized stratigraphic column for the Columbia River Basalt Group in Silver Falls State Park. 


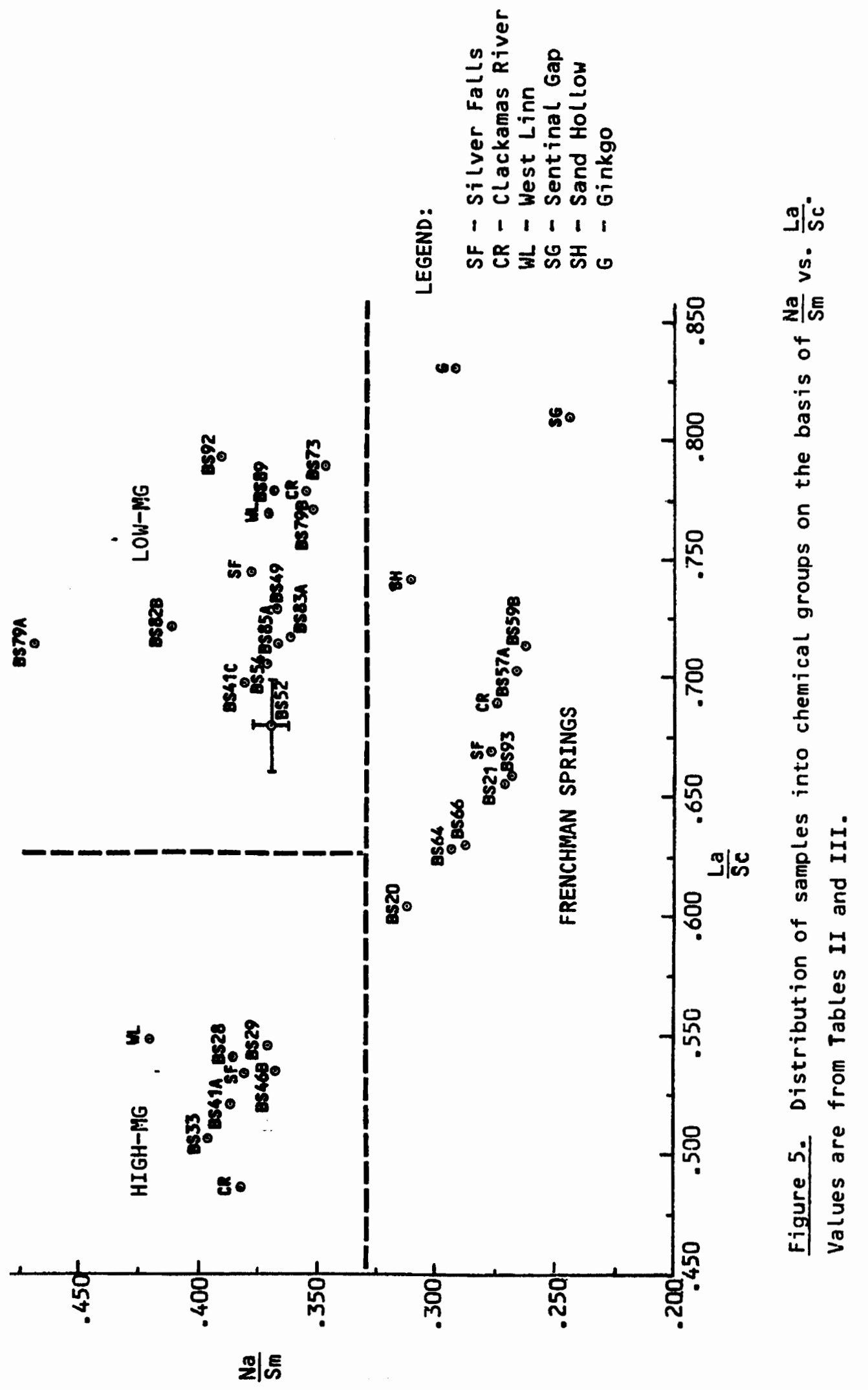




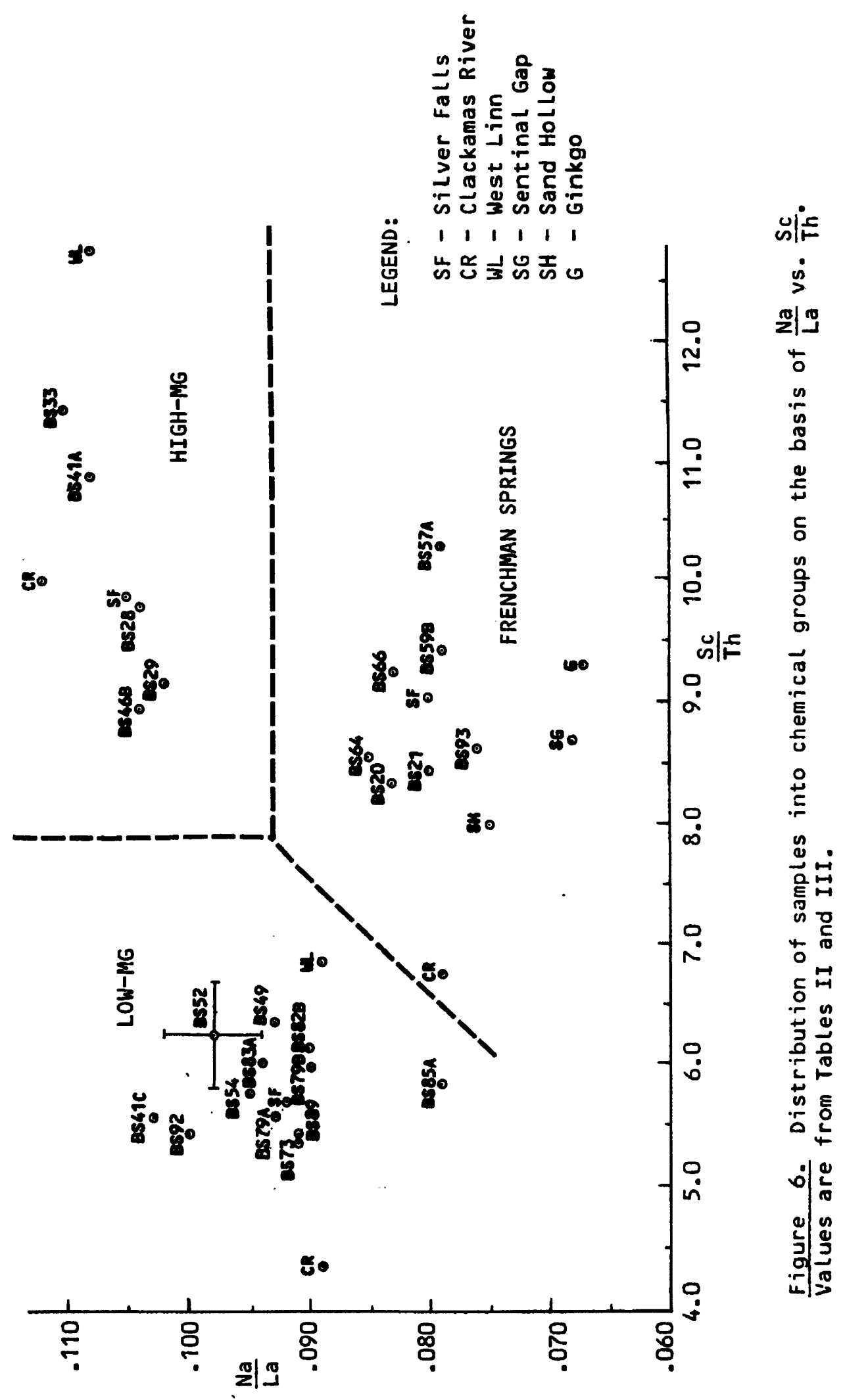


FRENCHMAN SPRINGS MEMBER - GEOCHEMICAL COMPARISON OF FLOWS AT SILVER FALLS STATE PARK WITH FLOWS FROM THE TYPE LOCALITIES AND THE CLACKAMAS RIVER AREA

\begin{tabular}{|c|c|c|c|c|c|}
\hline & $\begin{array}{l}\text { Clackamas } \\
\text { Kiver* } \\
\text { (Phree Lynx } \\
\text { section) }\end{array}$ & $\begin{array}{l}\text { Sentinal } \\
\text { Gap** } \\
\text { (type } \\
\text { locality) } \\
\end{array}$ & $\begin{array}{c}\text { Sand } \\
\text { Hollow** } \\
\text { (type } \\
\text { locality) }\end{array}$ & $\begin{array}{l}\text { Ginkgo** } \\
\text { (type } \\
\text { locality) }\end{array}$ & $\begin{array}{c}\text { Silver } \\
\text { Falls } \\
\text { (sectior) }\end{array}$ \\
\hline $\mathrm{Na}$ & 2.03 & 1.93 & 1.99 & 1.03 & 2.27 \\
\hline Ia & 25.6 & 28.2 & 26.7 & 28.6 & 28.4 \\
\hline $\mathrm{Sm}$ & 7.4 & 7.9 & 6.4 & 6.6 & 8.2 \\
\hline $\mathrm{Fe}$ & 10.8 & 11.0 & 11.1 & 11.1 & 12.5 \\
\hline $\mathrm{Ce}$ & 53.0 & IN. D. & II.D. & N.D. & 65.0 \\
\hline$E u$ & 2.2 & 2.2 & 2.2 & 2.2 & 2.6 \\
\hline Iu & .64 & N.D. & $N . D$. & N.D. & .59 \\
\hline Th & 5.5 & 4.0 & 4.5 & 3.7 & 4.7 \\
\hline $\mathrm{Hf}$ & 5.4 & 5.0 & 4.6 & 4.5 & $5 . ?$ \\
\hline Co & 42.8 & 38,6 & 39.2 & 37.4 & 48.5 \\
\hline$S c$ & 37.2 & 34.8 & 36.0 & 34.4 & 42.5 \\
\hline $3 a$ & 770 & 735 & 700 & 730 & 757 \\
\hline$n /$ & $6 /$ & 1 & 1 & 1 & $3 /$ \\
\hline
\end{tabular}

* Anderson, (1978)

** data from A.R.H.C.O., (1976)

n/ number of flows or flow units averaged 


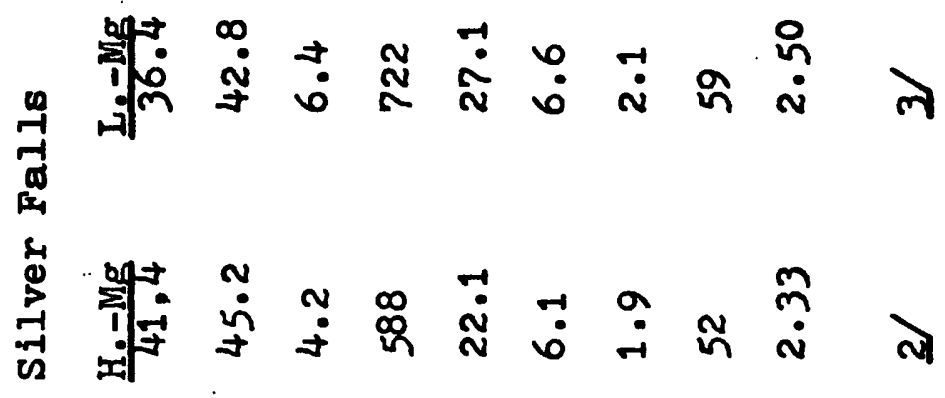

'出养

岩文

之w

专点

密沓敉

*

울르눈

留 突氙怘

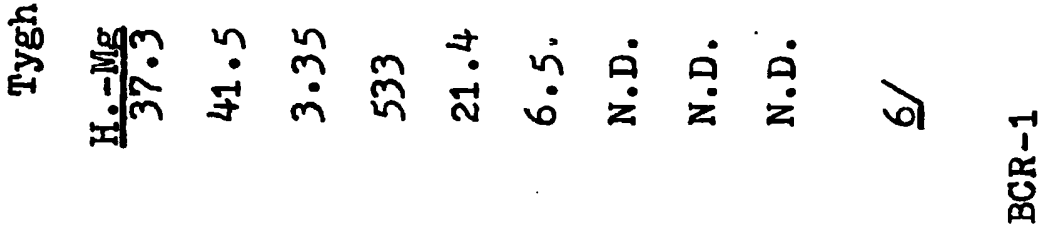

要

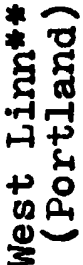

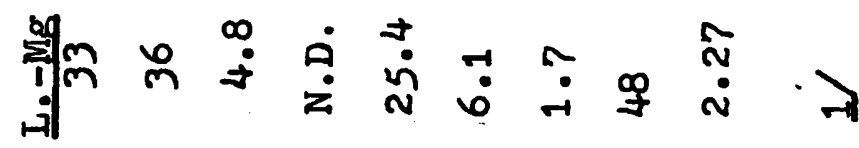

넝

돈현애

동닝 岁

종옵

号农焉

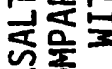

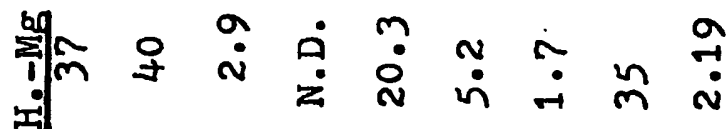

ता ‡

岩志

ฐ

\$?

㭊

总出

$\rightarrow$

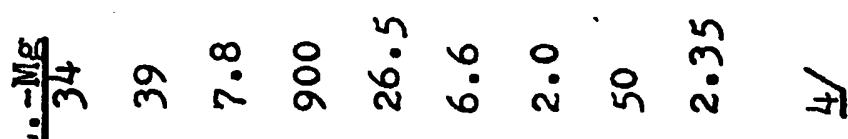

$$
\text { a }
$$

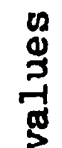

त

蛋

$\prod_{m}^{\infty} \stackrel{9}{=}$

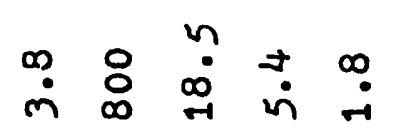

웅

तो

क्ष

\%ิ क्षै

\& సे 
fairly close together for the same chemical type, whereas Atlantic Richfield Hanford Company's (A.R.H.C.O.) (1976) values for Frenchman Springs type localities in eastern Oregon (Table II, Gingko, Sentinel Gap, Sand Hollow), using different equipment, do not agree with the Frenchman Springs from western oregon.

The geochemical data supports the field evidence for a normal sequence of Frenchman Springs overlying High-Mg Grande Ronde, then Low-Mg Grande Ronde along both North and South Silver Creeks. About a mile below the confluence of the two streams, the normal section is complicated where a 150 m thick intracanyon section of Frenchman springs rests directly on Low-Mg Grande Ronde with High-Mg Grande Ronde removed by erosion. Silver Creek canyon cuts through this intracanyon unit for about $0.5 \mathrm{~km}$, then reenters Low-Mg units (Figure 7 and Map). No High-Mg units were discovered beyond where silver Creek passes out of the intracanyon section, although the canyon below this point is capped by Frenchman Springs flows. No samples were analyzed from immediately below the Frenchman Springs flow; consequently the possibilfty exists that a High-Mg unit is present and unrecognized. As a result, the Frenchman Springs/High-Mg boundary is mapped with uncertainty.

Three samples deviate from what was expected. BS41C and BS83A are quite similar geochemically, appearing to be transitional between the Low-Mg and High-Mg. This type of 


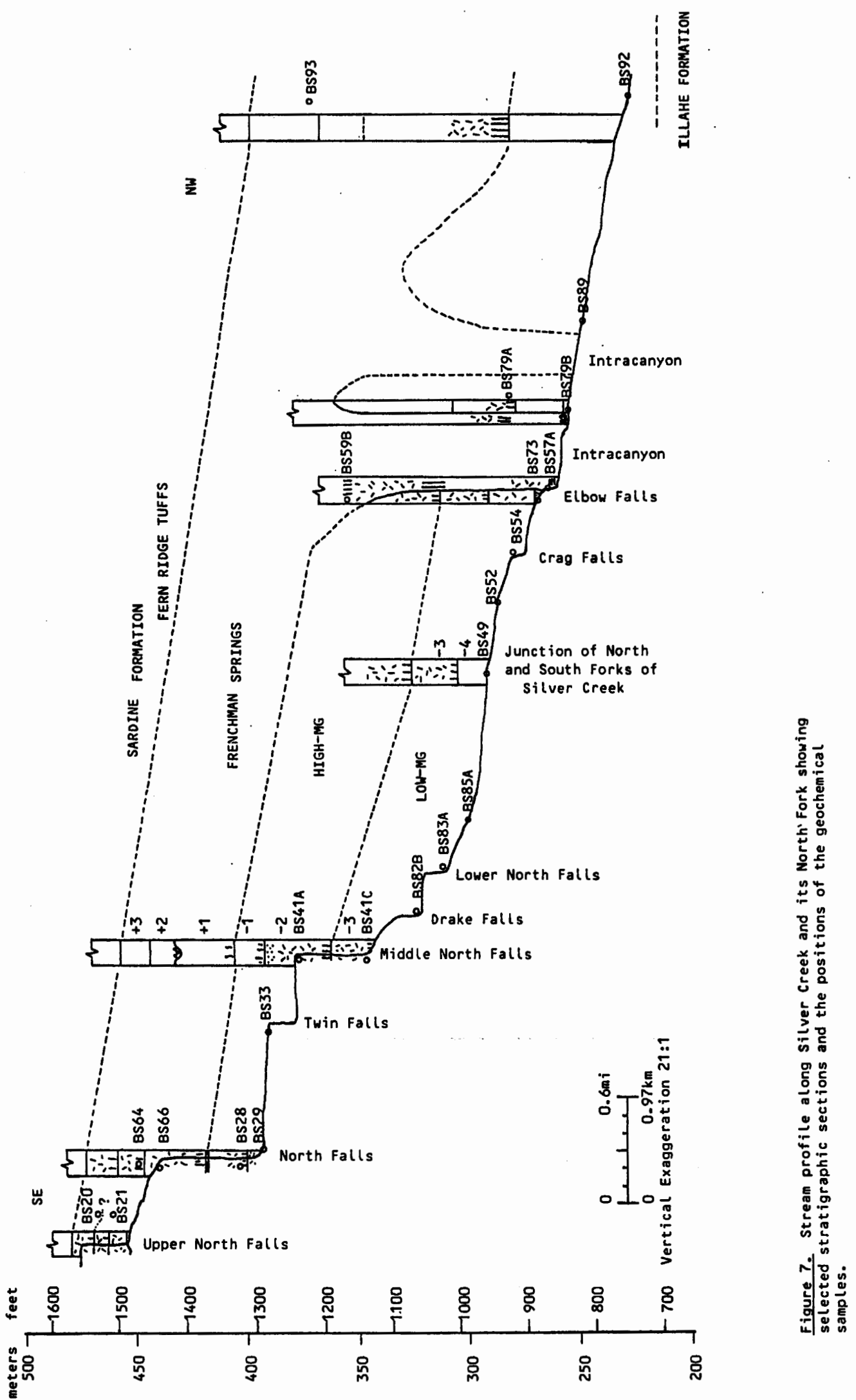


unit has been found elsewhere at the High-Mg/Low-Mg boundary; however, in this case they are separated by a unit (sample BS82B) which has characteristically Low-Mg chemistry. Three options seem possible: 1) the geochemistry is in error (not considered likely), 2) there has been tectonic deformation or step faulting for which there is no conclusive field evidence, 3) the upper transitional unit has flowed into an irregularity in the lower unit causing the transitional unit to appear lower stratigraphically. Jointing characteristics along the creek below lower North Falls indicate a disruption of both the transitional and the lower unit either as they flowed over this spot or afterwards (see Structure).

In both the first and second gamma-ray counts, Fe and Sc were high for these two samples, as was La, causing them to resemble Frenchman Springs geochemically in some respects (Table I). The highest Low-Mg unit sampled after the intracanyon (BS79A, see map for location) did not show transitional geochemistry.

Sample BS20 was from the highest unit sampled, just below the Fern Ridge tuffs. It was a fresh sample from the middle of the flow. In outcrop and hand specimen it appeared nearly identical with the rarely phyric Frenchman Springs flow which it conformably overlies. Its geochemistry, however, is quite distinct from all the other units sampled. From its position in the sequence it was 
expected to be a second, rarely phyric, Frenchman Springs flow, but its concentrations for all of the reliable elements were consistently more than $30 \%$ lower than those of Frenchman Springs flows and substantially lower than the values for High-Mg and Low-Mg Grande Ronde flows. Its chemistry most resembles a Pomona flow which is found in this stratigraphic position as an intracanyon flow in other areas (Anderson, 1978). A major drawback to this explanation for the anomolous flow (henceforth referred to as the North Creek Flow) is that it has normal polarity while the Pomona flows are reversed. Elemental abundance ratios computed for the flow in question were comparable to ratios of the same elements for Frenchman Springs samples. The discrepancy might be due to an error in weight since that seemed to be the only variable common to all the determinations for this sample, but the weight was checked and found to be correct. Upper North Falls was the only place where this second rarely phyric flow above the Vantage horizon could be identified. It would then seem that Pomona flows are not present in the thesis area. In addition, Prineville flows and Waverly flows found in western Oregon (Beeson and Moran, 1976) were not identified. It remains to be seen whether these flows will be found as far south as Salem by other workers. Physical Characteristics

Grande Ronde Basalt. In the canyon of Silver Creek, 
the subdivisions of Grande Ronde Basalt (Low-Mg and High-Mg chemical types) cannot easily be distinguished by physical characteristics. Due to time limitations, no petrography was done on the flows, therefore all characteristics are field determined. All the Grande Ronde Basalt flows exposed in this area possessed normal magnetic polarity.

The lowest unit exposed on silver Creek is a Low-Mg flow (normal polarity) with a hackly entablature estimated to be $10 \mathrm{~m}$ whose base is not exposed. This unit, like most of the Low-Mg flows, is very dark gray, fine grained, and contains quite rare clear plagioclase crystals less then three millimeters in length. Locally the lowermost Low-Mg flow may be separated from the Low-Mg above it by a massive light tangray, silty clay interbed about $3 \mathrm{~m}$ thick. The interbed breaks along irregular carbonaceous layers, lacking bedding. The flow above the interbed is a basalt similar to the lowest unit. This flow is covered by vegetation and talus from above. The third flow up from the river is the highest Low-Mg unit sampled downstream from the interruption of the section by the intracanyon Frenchman springs flow. Its broad columns nearly six $m$ high were the tallest seen in the Grande Ronde. The hackly entablature rises for over $6 \mathrm{~m}$ above the columns (Figure 7). The basalt is dark gray, dense, with small rare clear plagioclase crystals. Upstream from the intrcanyon flow, three flows are exposed below the High-Mg/Low-Mg boundary. Only the top 
of the lowest flow $(-5)$ is visible as the sequence is interrupted by the intracanyon flow. The second flow down $(-4)$ is gray to dark gray with rare small plagioclase crystals and a fine grained, almost sugary, texture. This flow, which is difficult to measure, seems to range in thickness from 15 to $21 \mathrm{~m}$. The basal columns are up to $1.5 \mathrm{~m}$ in diameter with platy bottoms. A single set of columns is more than $3 \mathrm{~m}$ high, but the columnar portion of the flow is more than $5 \mathrm{~m}$. The basal columns are vertical but are separated locally from the thick entablature by irregular columns or by platy or blocky jointing; some columns exposed in the stream beds are nealy horizontal. The first Low-Mg flow $(-3)$ below the High-Mg flow is $23 \mathrm{~m}$ thick and is similar in hand specimen appearance to the other Low-Mg flows except that it may be locally coarser grained. Its larger entablature often slopes back from the short wall formed by its basal, and in places platy, columns. This is the unit with the transitional geochemistry discussed above.

Two High-Mg flows lie between the Vantage horizon and the Low-Mg flows. They are dark gray, weathering to light gray; contain rare clear plagioclase crystals up to three or four millimeters long; are generally coarser textured than the Low-Mg flows, although they may be locally fine grained. The lower flow $(-2)$ is a thick $(34 \mathrm{~m})$ unit over $70 \%$ of which is entablature. The entablature may contain thin wavy 
columns and vesicular zones. This lower flow has a thick vesicular zone at the top and distinct basal comumns in places $1.2 \mathrm{~m}$ wide and more then $3 \mathrm{~m}$ tall. It is a cliff former and can be traced laterally as an aid in mapping the High-Mg/Low-Mg boundary. This contact is readily visible in Middle North Falls (Figure 8b) and Lower South Falls. The upper flow $(-1)$, deeply weathered on the top, is 12 to $15 \mathrm{~m}$ thick with local basal columns. At North Falls the columns are accompanied by local basal pillows. The outcrop appearance of the lower High-Mg flow $(-2)$ resembles that of Low-Mg flows as described in other areas by Anderson (1978) and Beeson (1976).

Vantage Horizon. Sufficient time elapsed between the eruptions of the High-Mg Grande Ronde flows and the Frenchman Springs flows to allow considerable erosion and some deposition of sediment to occur on the High-Mg flow surface before being covered by Frenchman Springs flows. In eastern Oregon this interbed is sufficiently thick and continuous to be mappable and has been named the Vantage Formation (Swanson, 1979). In western Oregon, sedimentary interbeds occur only locally and are referred to informally as the Vantage horizon which is considered to be correlative in time but not laterally continuous in space with the Vantage Formation.

The valley of the Silver Creek exposes both erosional and depositional features which were formed during the 


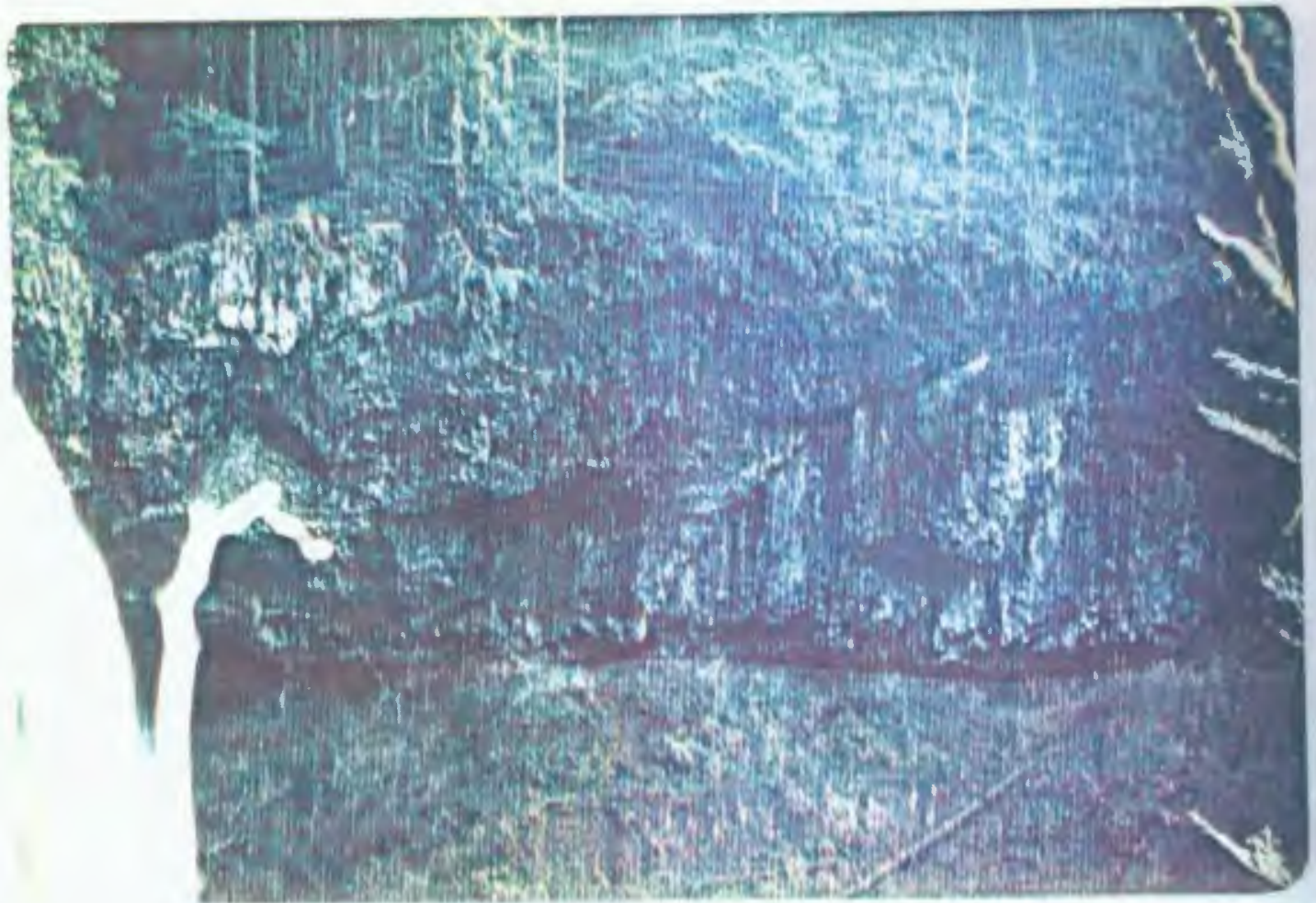

Figure 8. a. North Falls showing blocky jointing in the Frencliman Springs flows Lower Fence is on the Vantage horizon. b Middle North Falls at the Iligh-Mg/Low-Mg Grande Ronde Basalt boundary showing thick entablature and basal columns of the $\mathrm{High}-\mathrm{Mg}$

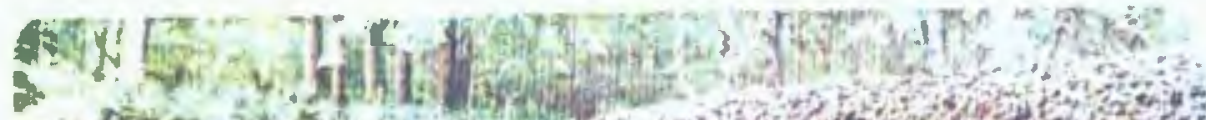

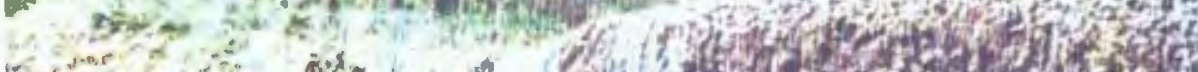

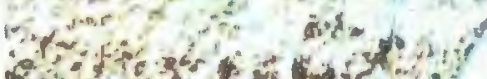

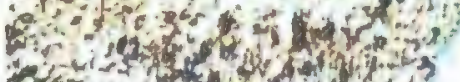

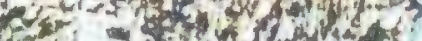

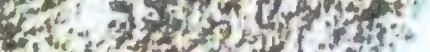

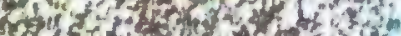

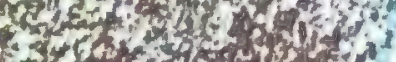

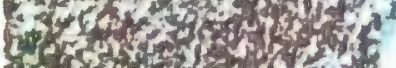

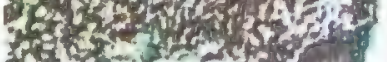

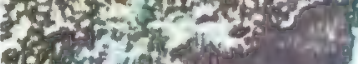
ote oration? 0 3.

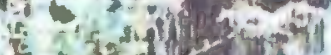
[5.5ent?

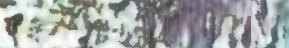
P.

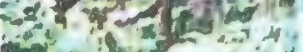

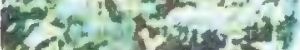

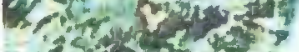
- interte?

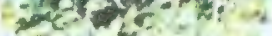
C.

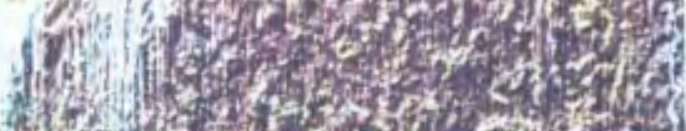

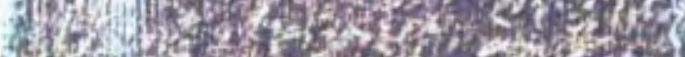

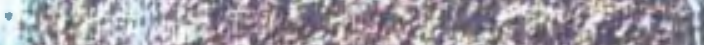

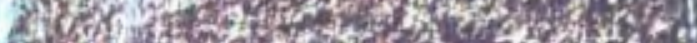

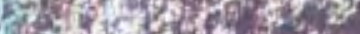

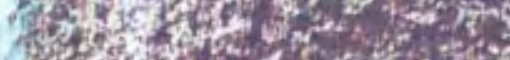

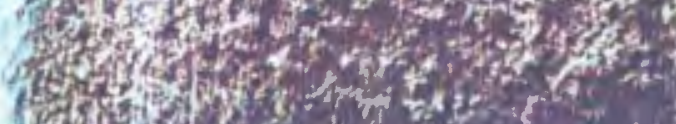

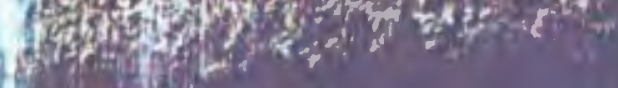

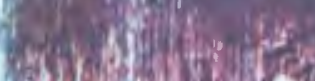

Q3)

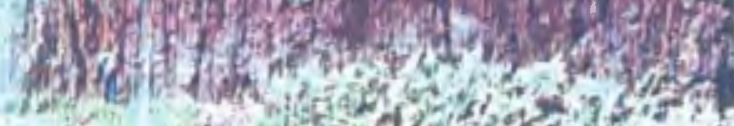

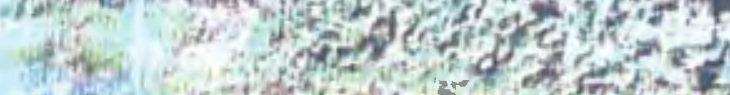

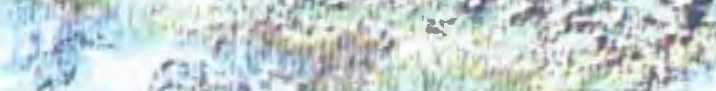


interval between the Grande Ronde and Frenchman Springs flows. Below the confluence of the forks of Silver Creek, evidence can be seen of a canyon that cut over $90 \mathrm{~m}$ deep through the High-Mg and well into the Low-Mg Grande Ronde Basalt. In the same time period, volcanic-derived sediments were being deposited nearby and elsewhere away from energetic streams. For the most part this sedimentary interbed is buried beneath the talus of the cliff-forming Frenchman Springs flows which lie over it.

The two best displays of these deposits are also major scenic attractions in the Park. Both North and South Falls have overhangs of the resistant Frenchman Springs with trails that pass behind the falls at the Vantage horizon. The Vantage horizon erodes back more rapidly than the lava flows forming an amphitheatre (particularly at North Falls where the Vantage interbed is thicker) floored by the weathered top of a High-Mg Grand Ronde flow, roofed by the base of a Frenchman Springs flow, with the Vantage interbed making up the anterior wall several centimeters to meters in height. At South Falls part of the Vantage interbed is light gray tuffaceous sediments with few crystals and carbonaceous fragments and separations. Graded beds of sandstone that fine upward from an erosional base to finely laminated mudstone a few centimeters thick indicate deposition by moving water. The sandstone is a fine-grained, iron-stained volcanic litharenite. At North Falls, the unit is a tan, 
moderately well-sorted, medium-grained sandstone comprised mostly of feldpathic and volcanic particles with minimal matrix. Thinly laminated beds form larger cross bedded groups tens of centimeters thick. The unit as a whole is 3 to $6 \mathrm{~m}$ thick. At both North and South Falls tree casts can be seen in the overhangs providing evidence of soils and forests that developed between incursions of lava.

Frenchman Springs Member of the Wanapum Basalt. Four distinct basalt flows of the Frenchman Springs Member of the Wanapum Basalt can be idenfified above the Vantage horizon. These flows are separated on the basis of outcrop characteristics such as vesicular zones at both the top and base of the flows, incipient columns, crude pillows, and palagonite; all can be easily observed near the waterfalls. All flows give a normal magnetic reading. The two lower flows are highly phyric, the two upper flows are rarely phyric.

The lowest Frenchman Springs unit (+1) flowed in over the topography created during vantage time. This flow, a distinct cliff former, is 18 to $24 \mathrm{~m}$ thick, but where it becomes an intracanyon flow, it is over $100 \mathrm{~m}$ thick. This flow generally has blocky to columnar jointing with a hackly entablature. At South Falls the outcrop appearance is more irregular with palagonite at the base of the flow. As an intracanyon this flow has well-formed vertical columns (approximately $6 \mathrm{~m}$ high) near the top in places. 
Near the base and edge of the intracanyon portion of the flow there is an impressive outcrop of well-developed horizontal columns some $5 \mathrm{~m}$ in length and continuing for around $75 \mathrm{~m}$ (Figure 10a). On the hillside just above the horizontal columns short stubby columns are leaning forty degrees from the vertical toward the southwest. Downstream, outcrops of palagonite begin to occur. They continue for more than $150 \mathrm{~m}$ and are more than $3 \mathrm{~m}$ thick in areas. These, along with joint patterns, indicate the base and edge of the intracanyon portion of the flow.

This flow is easily distinguished from the Grande Ronde flows since it has abundant large (up to two centimeters) plagioclase phenocrysts in a glomeroporphyritic texture as well as microphenocrysts of plagioclase. There are rare local spots where phenocrysts are hard to find, making identification of the outcrop more difficult. The dark gray matrix is generally coarser than Grande Ronde Basalt but there are local spots where it is fine grained, making correlation more difficult than if the unit had consistent characteristics.

The second flow unit up from the vantage horizon is similar enough in hand speciman to the first so that they can only be distinguished by finding a contact and determining the stratigraphic sequence. The texture is coarse, the color dark gray, the plagioclase abundant as both phenocrysts and microphenocrysts. In areas of abundant plagioclase, large phenocrysts could be found in every 
sample broken off the outcrop and hand sized samples often had two or more phenocrysts. This unit has poorly-developed, basal columnar joints forming blocks of about one meter maximum in diameter.

Sufficient time elapsed between the first Frenchman Springs flow and the second for channeling to take place in the top of the first. The contact is marked by palagonite in many areas and channels at South Falls, Winter Falls and Upper North Falls. The channel at Winter Falls, for example, has a maximum depth of approximately $6 \mathrm{~m}$ with a width of about $14 \mathrm{~m}$ and is filled with basalt of a pillowy nature (Figure 9). The contact between the two units shows a slight dip to the west (approximately one to two degrees). This second unit up has normal magnetic polarity, is generally about $12 \mathrm{~m}$ thick and shows the traditional ropey top of pahoehoe lava where it has been preserved.

The third Frenchman Springs flow $(+3)$ above the Vantage horizon is very dark gray, fine-grained, dense, with microphenocrysts of plagioclase. Large $(1-2 \mathrm{~cm})$ plagioclase phenocrysts are rare; in five or six.rock samples one large crystal might be found. The unit has normal magnetic polarity. It is from 6 to $15 \mathrm{~m}$ thick with rather crude columns at the base of the flow. Above that the unit is more hackly and breaks into twelve centimeter platy chunks. The second and third Frenchman Springs flows are cliff formers yet above a cliff of the first flow they will often 


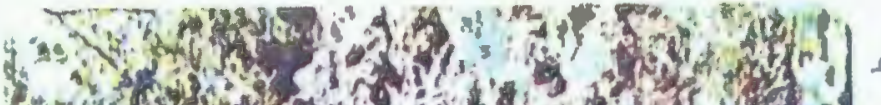

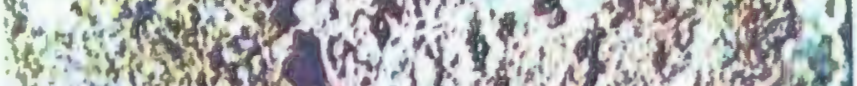

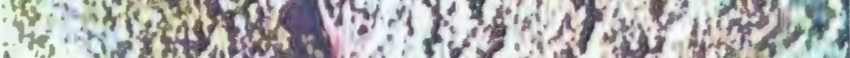

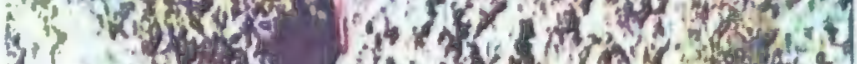

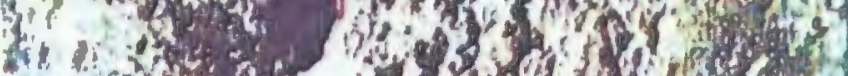

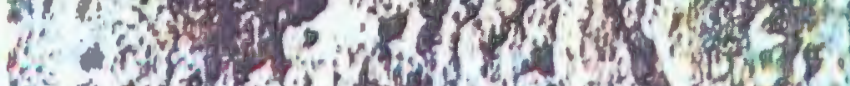

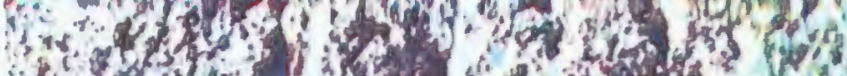

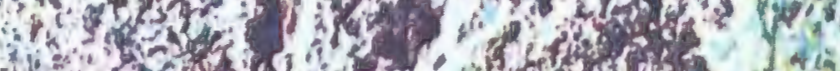
(x)

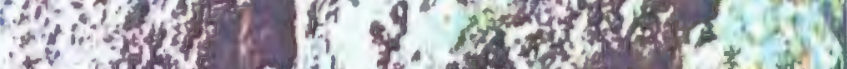

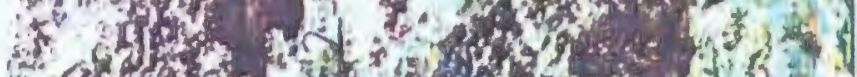

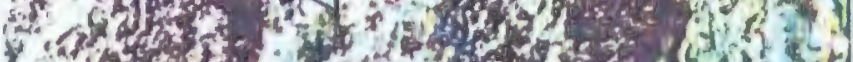

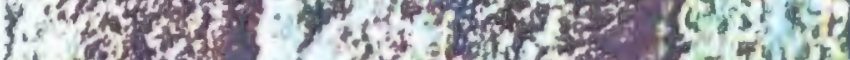

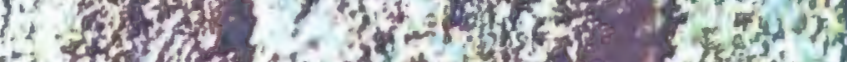

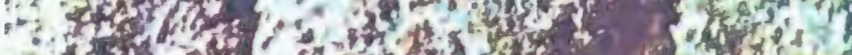

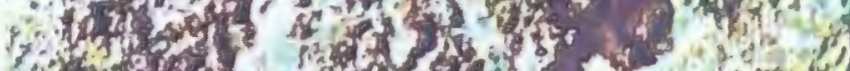

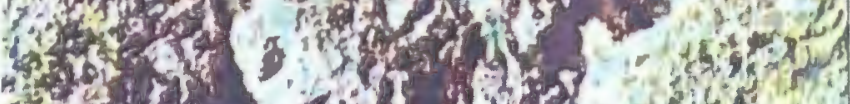

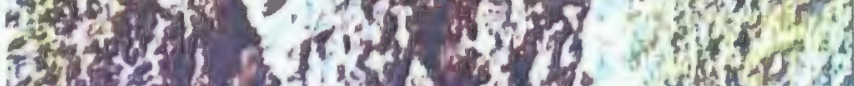

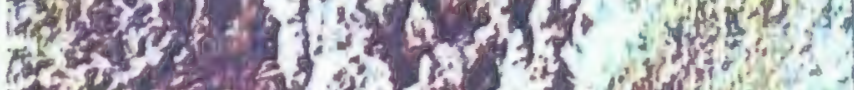

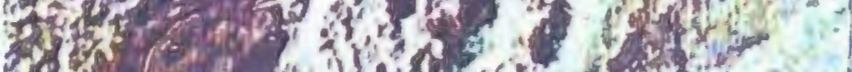

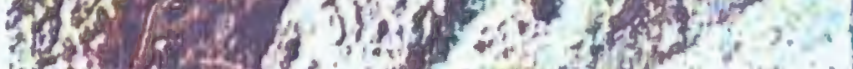

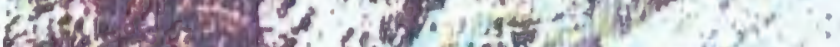

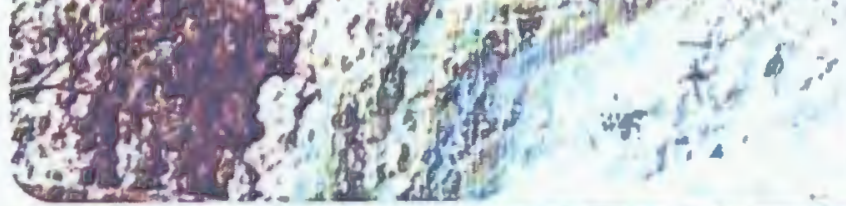
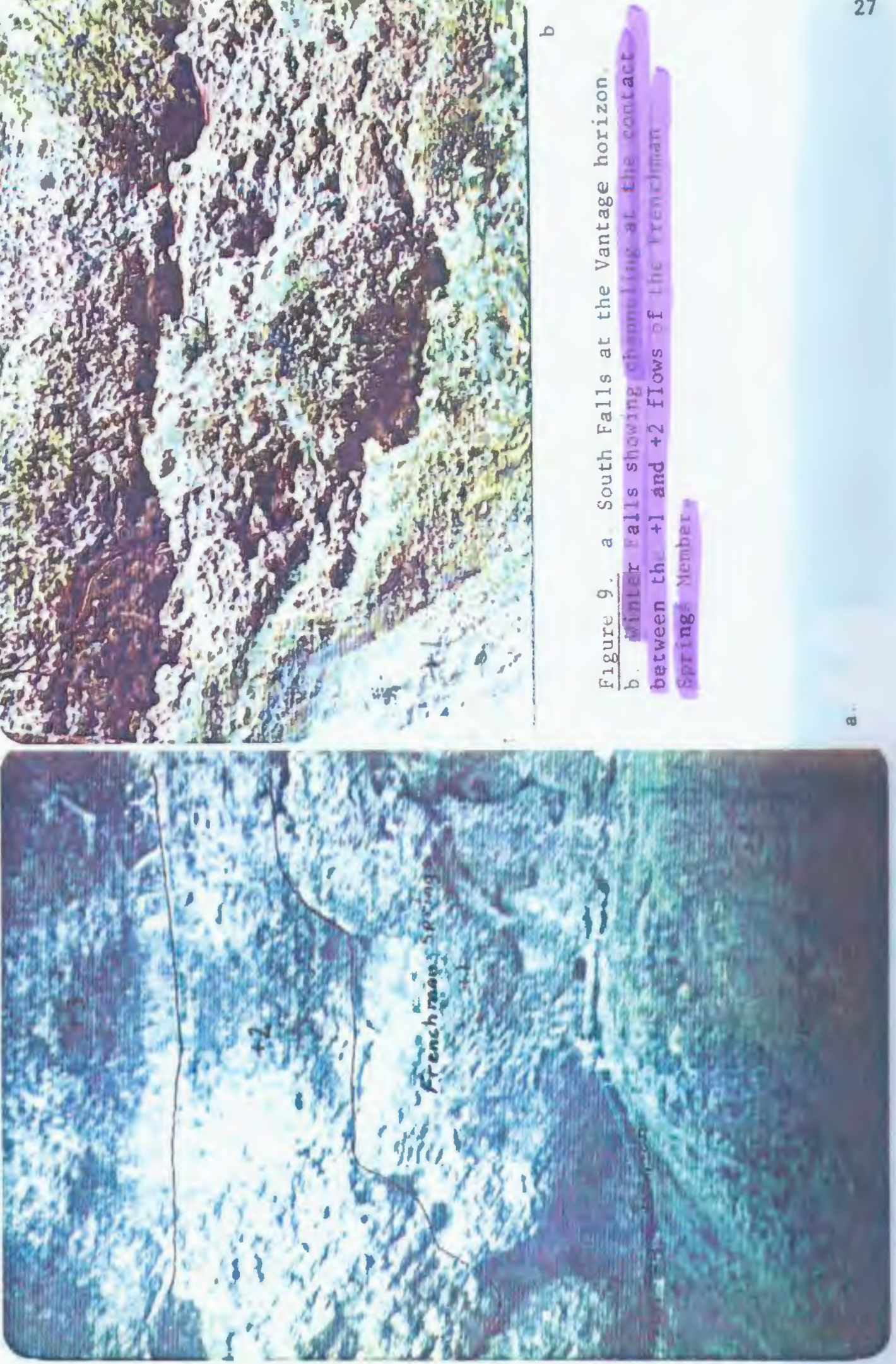


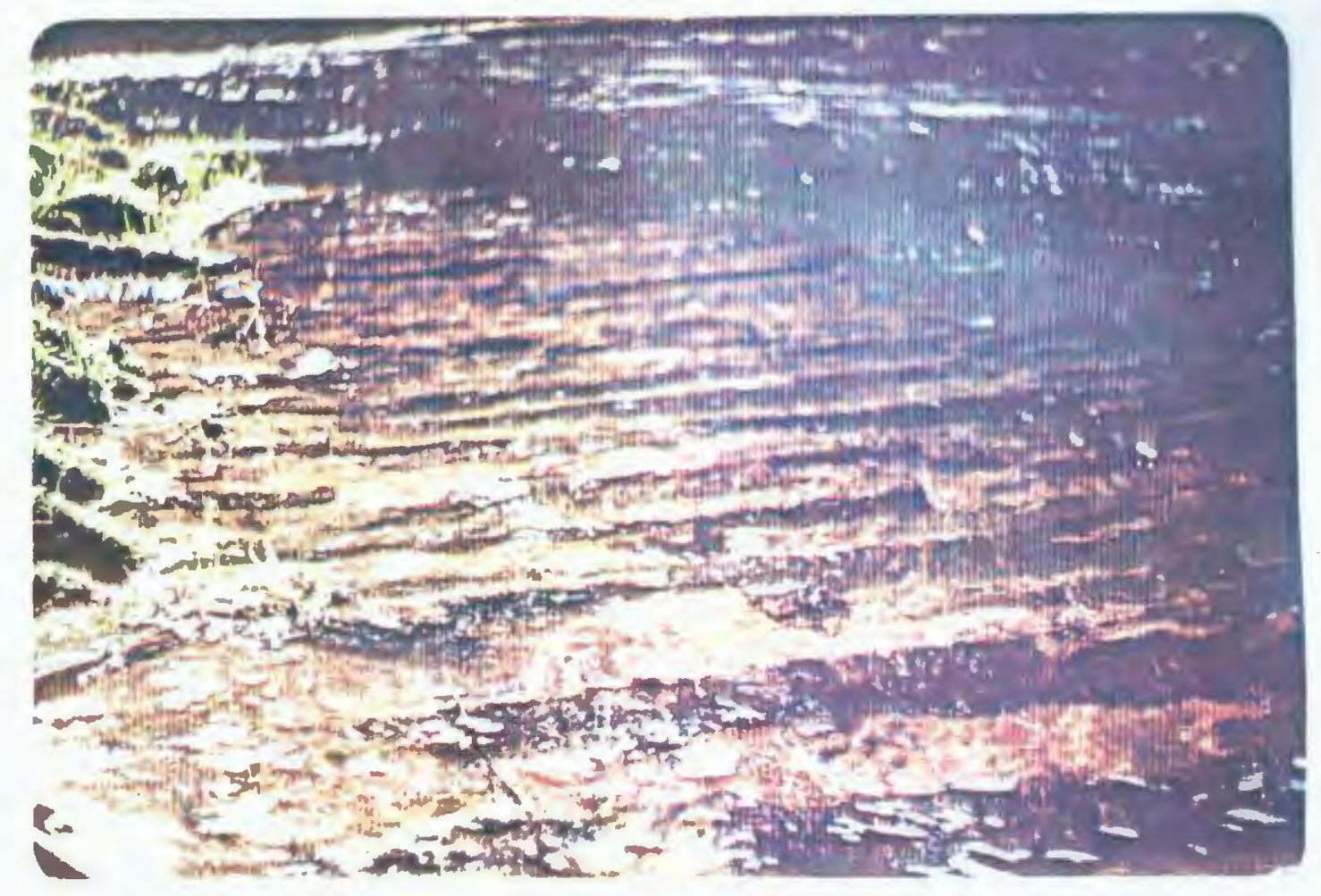

figure 10. a Horizontal $\rightarrow$ umins near the edge of the intracanyon portion of the Fr nchman Springs Member

b. The intracanyon Elow at Elbow Falls, joints dipping $40^{\circ} \mathrm{SE}$.

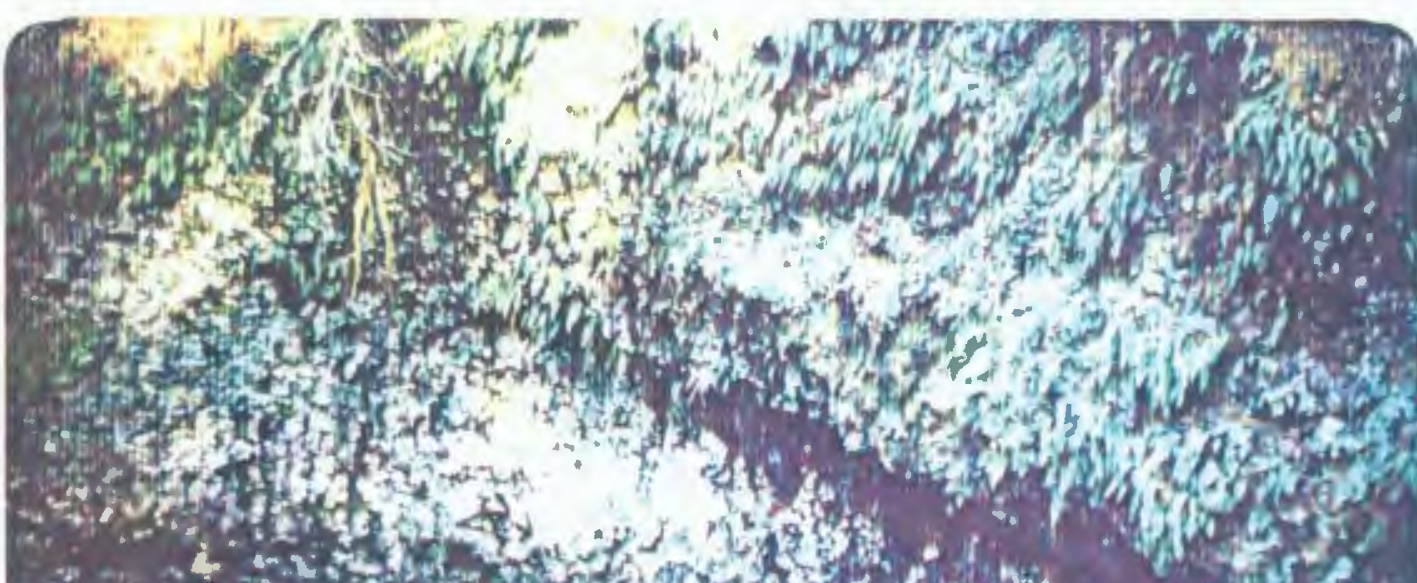

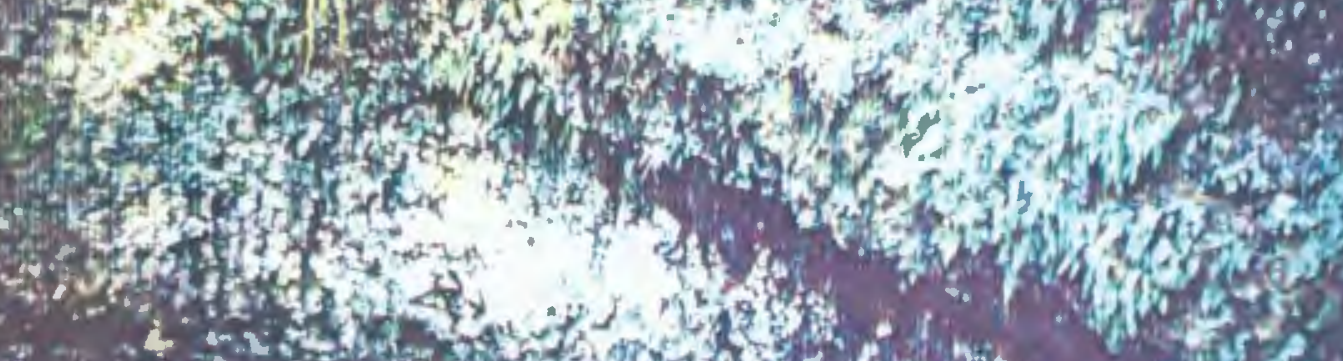

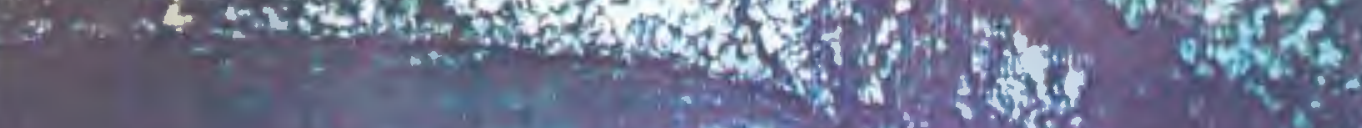

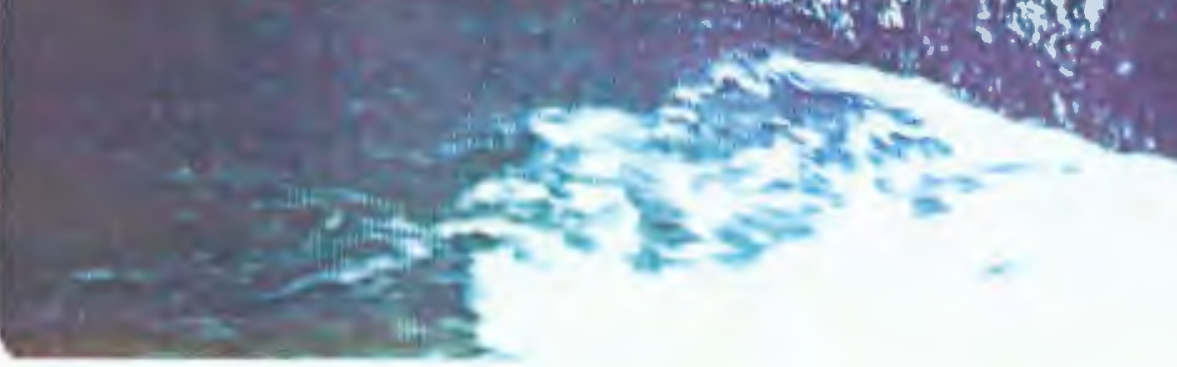


be hidden by rubble, soil, and brush on a very steep slope. The fourth flow up, the highest unit sampled (the North Creek flow), is some what of an enigma. In hand specimen and outcrop appearance the two rarely phyric flows, the third and fourth, are similar. The North Creek flow is from 6 to $9 \mathrm{~m}$ of dark gray, fine grained basalt with incipient columnar jointing. Its geochemistry is more like a Pomona flow than the Frenchman springs flows, but its normal polarity is evidence that it is not a Pomona flow. This flow could be positively identified only at Upper North Falls and along the trail into it. In other areas, only three distinct Frenchman springs flows were seen. If the North Creek flow is present it is hidden under the steep vegetation covered slopes that topped the sheer outcrops. Or is may have been deeply weathered or eroded in most places prior to the deposition of the Fern Ridge Tuffs.

\section{Correlation}

Some correlation within the area is based on stratigraphic position, outcrop characteristics, and hand specimen analysis, while other determinations require geochemical analysis. The Vantage horizon can be found on the basis of field characteristics alone. The stratigraphic sequence from the top down consisting of two rarely phyric flows, two phyric flows, a time horizon indicated by sand lenses and tree casts, then numerous aphyric flows, matches that described in other areas west of the Cascades (clacka- 
mas River, Anderson, 1978; West Iinn, Beeson and others, 1976). The Vantage horizon can be traced throughout silver Falls State Park. Geochemical analysis provides confirmation and is also used for direct correlation with other areas.

Anderson (1978), in his study of the Columbia River Basalt in the Clackamas River area, described the Frenchman Springs flows as having more of a blocky than a columnar outcrop appearance, the Low-Mg flows to have a welldeveloped basal colonade with more than $50 \%$ of the flow forming a large entablature, and the High-Mg flows to resemble the Frenchman springs flows in outcrop. In Silver Falls State Park the Frenchman Springs flows continue to have a blocky colonade, the Low-Mg flows have a welldeveloped colonade with a large entablature but the High-Mg flows closely resemble the Low-Mg flows in outcrop appearance rather than the Frenchman Springs.

The Low-Mg flows are usually fine grained, but the HighMg flows are not consistently coarse grained. In all other respects the two groups of flows are indistinguishable. This created a problem with correlation within the Park. Where samples were analyzed for trace elements, it is possible to separate the flows into High-Mg or Low-Mg. Since the intracanyon flow interrupted the lateral continuity of Low-Mg flows it is difficult to determine the total thickness and total number of flow units present. 
An attempt was made to tie in the sequence downstream of the intracanyon with that determined geochemically upstream of the intracanyon by identifying the vantage horizon and the Low-Mg/High-Mg boundary on a tributary creek that entered Silver Creek about a half of a kilometer north of the intracanyon flow. Samples were taken and studied but geochemistry was not used. Assuming the one to two degree westerly dip is maintained, the High-Mg flows should be present as indicated on the map (Figure 12). The hand specimens are all similar and no coarse-grained/finegrained boundary indicating a crossing of the High-Mg/LowMg contact can be distinguished. 


\section{STRUCTURE}

The limited area covered by this work precluded the description of previously described folds in the area. The terrain covered lies between two open, gentle anticlines in a series of en echelon folds on the western edge of the Western Cascades (Peck and others, 1964; Thayer, 1939). These have been described under Regional Geology (Figure 3). Attitudes taken from columns and contacts were generally found to reflect local irregularities in topography that the unit flowed over. A gently west southwest dip of two to three degrees was found by noting the change in elevation of two parallel boundaries: the Frenchman Springs/Vantage horizon boundary and the High-Mg/Low-Mg boundary. This dip is most likely due to gentle folding after solidification.

There seems to be two main directions of jointing perpendicular to one another that resulted in pervading fractures in the units. Between the oligocene and the Middle Miocene the marine sedimentary rocks that underlie the basalt were folded. Later the basalts and the units overlying the basalts were folded gently. Regional dips and folding may have partly controlled the courses of streams which lava flows later followed.

Just downstream from Upper North Falls and just upstream from North Falls distinct fractures in the Frenchman Springs flows have been accentuated by the moving water. 
They appear vertical with bearings $\mathrm{N} 20^{\circ} \mathrm{W} \pm 5^{\circ}$. At Elbow Falls, where the units change abruptly from Low-Mg Grande Ronde to the Frenchman Springs of the intracanyon, the river makes a nearly right angle turn from $\mathrm{N} 30^{\circ} \mathrm{W}$ to $\mathrm{s} 70^{\circ} \mathrm{W}$. Major foints above the falls have strikes of $\mathrm{N} 70^{\circ} \mathrm{E}$, the same as the river. Secondary joints have bearings slightly west of north. Below the falls, for a hundred meters along the creek bottom lie well-formed horizontal columns perpendicular to the flow of water $N 20^{\circ} \mathrm{W}$ (Figure 10a). Above the stream level the columns are about $1.5 \mathrm{~m} \mathrm{high}$ and are more crudely formed. They stand perpendicular to a surface with a strike and dip of around $\mathrm{N} 30-70^{\circ} \mathrm{E} 40^{\circ} \mathrm{SE}$ (Figure 10b). Similar patterns are repeated in the stratigraphically lower Low-Mg Grande Ronde Basalt. Downstream from Double Falls on North Silver Creek from the collection location of sample BS83A to the location of sample BS85A (Figure? map), the columns and fointing are irregular. For the most part flow units have vertical columns at the base of the flow with a hackly entablature. This area is different in that there are parallel horizontal joints separating short vertical columns. Downstream from sample location BS83A, the horizontal joints begin to dip $11^{\circ}$ to the northwest while the columns remain perpencicular to the jointing. Further downstream the dips are steeper, up to $25^{\circ}$ to $30^{\circ}$ to the west. In some spots the columns remain vertical while the joints dip. Flows visible higher up in the walls 
of the valley remain horizontal. This is the same area that the unit of transitional geochemistry was found at two elevations. These irregularities do not show up in the traverse along South Silver Creek. The simplest explanation would be that there was a topographic irregularity that the molten flow encountered which affected the lavas' cooling pattern. As a second possibility, deformation affecting the jointing pattern may have taken place after cooling but prior to being covered by High-Mg flows.

Downstream about $0.3 \mathrm{~km}$ beyond the junction of North and South Silver Creeks, nearly horizontal columns were found in Low-Mg units that are oriented perpendicular to those found in the Frenchman springs intracanyon flow. These columns have a bearing of $N 75^{\circ} \mathrm{E}$. A plane perpendicular to the columns would have a strike and dip of $N 15^{\circ}$ W $70^{\circ} \mathrm{NE}$. The columns are vertical again for about a half a kilometer, then the river begins to run parallel to a platy jointing in the basalt with a strike of $N 70^{\circ} \mathrm{E}$. A combination of regional stresses and variable terrain probably caused the system of fractures and cooling joints exposed today. 


\section{GEOLOGIC HISTORY}

During the oligocene the area was submerged beneath a sea. Volcanic sediments were being transported and deposited. A period of folding, uplift, and erosion took place before the Middle Miocene creating a topographic relief of about $120 \mathrm{~m}$. Over this terrain Low-Mg Grande Ronde flows came from the northeast, burying it. Between major extrusions, local volcanic eruptions deposited layers of ash. Stream drainages that had been cut off reestablished themselves. A fhange in chemistry at the source produced the High-Mg Grande Ronde flows that next invaded the region. Then sufficient time elapsed for a canyon to be eroded to a depth of over $90 \mathrm{~m}$, for a forest to grow, sand bars to be deposited. The first of the Frenchman Springs flows swept through, filling valleys and burying trees. Over time, the drainage pattern was reestablished as streams eroded the new lava flow. The cycle repeated itself with each succeeding flow until after the last flow a period of weathering took place that produced a deep lateritic soil over which the Fern Ridge Tuffs were deposited. The units were then gently bent between open anticlines. The present course of the Silver Creek crosses many of the ancestral streams. Weathering and erosion seem to be the current dominant processes. Farms abound on the dip slopes of weathered basalt units. 


\section{CONCLUSIONS}

In most cases, geochemical analysis provides positive identification of the Columbia River basalt flows present in an area, and serves as a correlative tool between separated areas of Columbia River basalt outcrops. The flows identified in the thesis area are as follows: 1) three to four flows of the Low-Mg chemical type of the Grande Ronde Basalt, the uppermost having geochemical abundances transitional between High-Mg and Low-Mg chemical types 2) two flows of the High-Mg chemical type of the Grande Ronde Basalt 3) three flows of the Frenchman Springs member of the Wanapum Basalt, the two lower being phyric, the uppermost being rarely phyric 4) one flow, the North Creek flow, of anomolous geochemistry but resembling the rarely phyric Fenchman springs flow in physical appearance. Further research is required to satisfactorily define the anomolous flow, its nature and extent. Except for the anomolous flow, there is no significant chemical difference between the flows in the Portland and Clackamas River areas and Silver Falls State Park.

There are, however, differences in physical characteristics. In the Portland and Clackamas River areas the High-Mg Grande Ronde Basalt is coarse grained with a blocky outcrop appearance. Along Silver Creek the High-Mg Grande Ronde Basalt tends to be finer grained with distinct well- 
formed basal columns and a thick hackly entablature closely resembling the Low-Mg Grande Ronde Basalt in outcrop. This change in appearance may be due to a loss of volatiles or cooling of the flow as it traveled farther from its source.

The thesis area is not very complex structurally. The area being small, the general trends cannot be accertained nor evaluated without reference to the literature. The flows dip west southwest two to three degrees on the limb of an open anticline. The most prominent jointing consists of two trends perpendicular to one another, $\mathrm{N} 20^{\circ} \mathrm{W}$ and N $70^{\circ} \mathrm{E}$, which appear to partially control the drainage pattern. The jointing is most likely related to anticlinal folding, the axes of which swing from $\mathrm{N} 35^{\circ} \mathrm{E}$ to $\mathrm{N} 65^{\circ} \mathrm{E}$ (Peck and others, 1961).

The single most interesting discovery made in the course of this study was the channel cut by an ancestral stream between incursions of the High-Mg Grande Ronde Basalt and the Frenchman Springs Member of the Wanapum Basalt. The stream carved a valley over $90 \mathrm{~m}$ deep in the Grande Ronde Basalt. On the basis of this small area the channel appears to be following the structural trend travelling $s 70^{\circ} \mathrm{w}$. More work is necessary to establish the ancient drainage patterns.* one unanswered question is whether

* Subsequent work has suggested the presence of the ancient channel in drainages surrounding Silver Creek (personal communication, Marvin H. Beeson, 1980). 
the stream flowed west to the sea or turned north to follow the present Willamette channel. Basalts have been found on the oregon coast which are geochemically similar to the Frenchman Springs Member of the Wanapum Basalt. If the stream flowed west it could have provided a channel by which the Frenchman Springs might have reached the coast. 

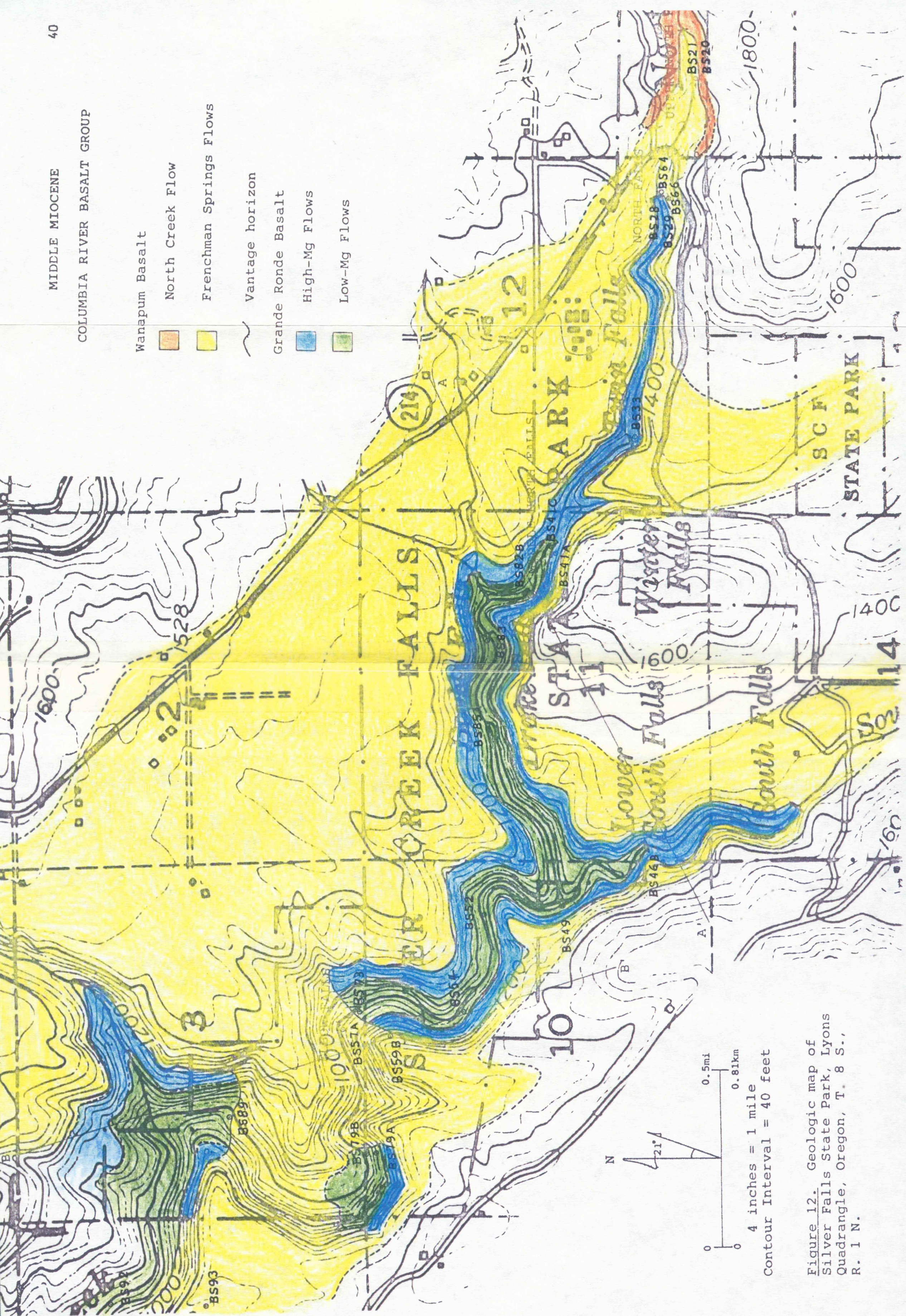

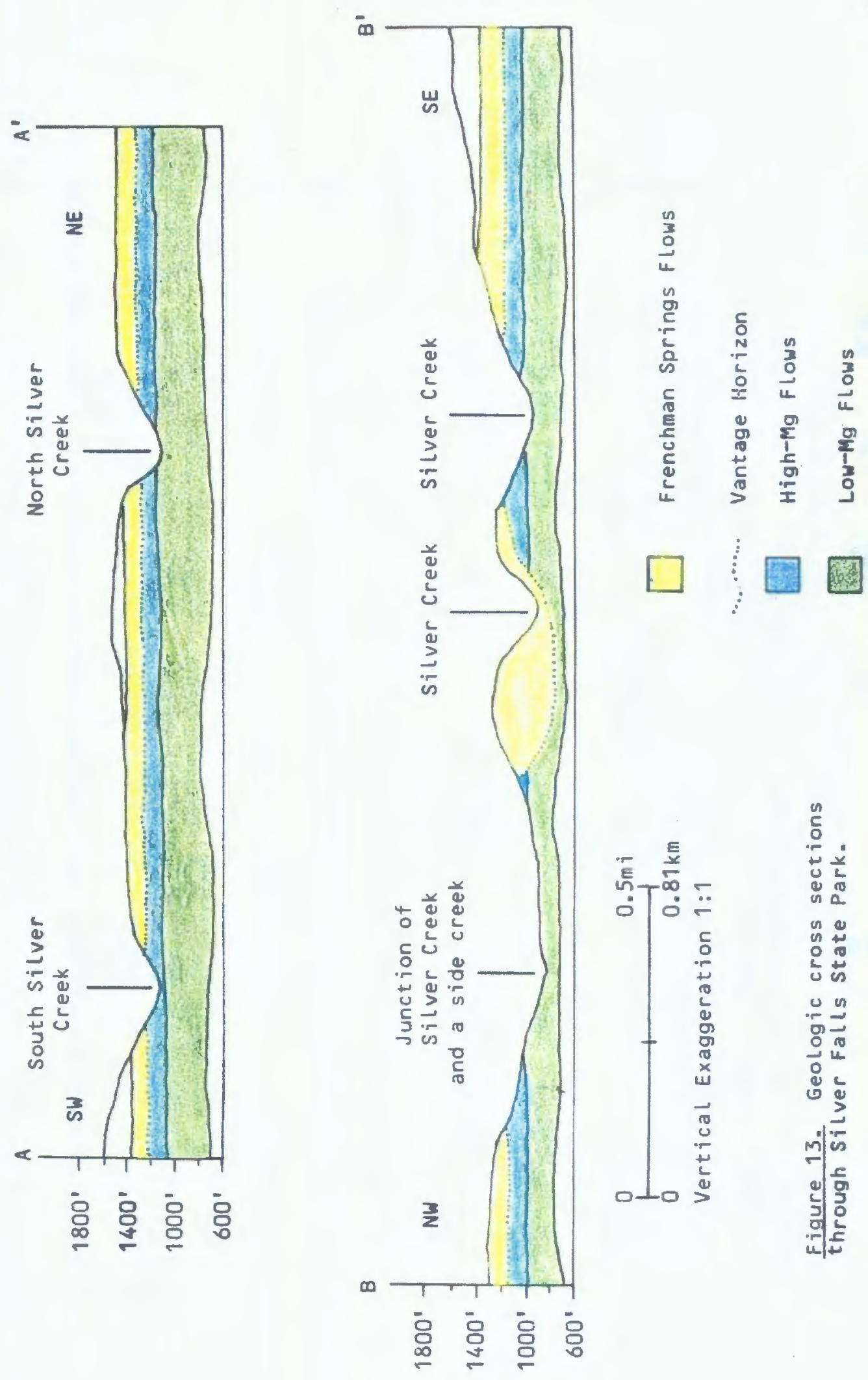


\section{REFERENCES}

Anderson, J.L., 1978, The Stratigraphy and structure of the Columbia River Basalt in the Clackamas River Drainage: Portland State Univ., unpub. master's thesis, $136 \mathrm{p}$.

Atlantic Richfield Hanford Company (ARHCO), 1976, Preliminary Feasibility Study of Storage of Radioactive wastes in Columbia River Basalts: ERDA Rept. ARH-ST-137, v. 1, p. 43 .

Barlow, J.L., 1955, The Geology of the central Third of the Lyons Quadrangle, Oregon: University of Oregon, unpub. master's thesis, $79 \mathrm{p}$.

Beeson, M.H., Johnson, A.G., and Moran, M.R., 1976, Portland Environmental Geology - Fault Identification: Final Technical Report to U.S. Geol. Survey, 107 p.

Beeson, M.H., and Moran M.R., 1979, Columbia River Basalt Group Stratigraphy in Western Oregon: Oregon Geology, v. 41, no. 1 , p. 11-14.

Flanagan, F.J., 1973, 1972 Values for International Geochemistry Reference Samples: Geochimica et Cosmochimica Acta, v. 37, p. 1189-1200.

Freed, M., 1979, Silver Falls State Park: Oregon Geology, v. 41 , no. 1 , p. 3-10.

Gordon, G.E., Randle, K., Gordon G.G., Corliss, J.B., Beeson, M.H., and Oxley, S.S., 1968, Instrumental Activation Analysis of Standard Rocks with High-resolution $\gamma$-ray Detectors: Geochimica et Cosmochimica Acta, v. 82, p. 369-396.

Nathan, S., and Fruchter, T.S., 1974, Geochemical and Paleomagnetic stratigraphy of the Picture Gorge and Yakima Basalts (Columbia River Group) in Central Oregon: Geol. Soc. America Gull., v. 85, p. 63-76.

Peck, D.L., Griggs, A.B., Schlicker, H.G., Wells, F.G., and Dob, H.M., 1964, Geology of the Central and Northern Parts of the Western Cascade Range in Oregon: U.S. Geol. Survey Prof. Paper 449, 56 p. 
Swanson, D.A., Wright, T.L., Hooper, P.R., and Bentley, R. D. , 1979, Revisions in Stratigraphic Nomenclaure of the Columbia River Basalt Group: U.S. Geol. Survey Bull. 1457-G, 59 p.

Thayer, T.P., 1937, Petrology of Later Tertiary and Quaternary Rocks of the North-Central Cascade Mountains in oregon: Geol. Soc. America Bull., v. 48, no. 11, p. 1611-1651.

--- 1939, Geology of the Salem Hills and the North Santiam River Basin, Oregon: Oregon Department of Geology and Mineral Industries, Bull. 15, $40 \mathrm{p}$.

Waters, A.C., 1961, Stratigraphic and Lithologic Variations in the Columbia River Basalt: American Jour. Science, v. 259, p. 583-611. 